\title{
Ullmann reaction through ecocatalysis: insights from bioresource and synthetic potential
}

Guillaume Clavé $^{1}$, Claire Garel ${ }^{1}$, Cyril Poullain ${ }^{1}$, Brice-Loïc Renard ${ }^{1}$, Tomasz K. Olszewski ${ }^{2}$, Bastien Lange $^{3,4}$, Mylor Shutcha ${ }^{5}$, Michel-Pierre Faucon ${ }^{3}$, Claude Grison*1

${ }^{1}$ Bio-inspired Chemistry and Ecological Innovations (ChimEco), FRE 3673 CNRS-University of Montpellier, Cap Delta, 1682 rue de la Valsière, 34790 Grabels, France

${ }^{2}$ Faculty of Chemistry, Wroclaw University of Technology, Wybrzeze Wyspianskiego 27, 50-370 Wroclaw, Poland

${ }^{3}$ Hydrogéochimie et Interactions Sol-Environnement (HydrISE), UP.2012.10.102, Institut Polytechnique LaSalle Beauvais (ISAB-IGAL), 19 rue Pierre Waguet, FR-60026 Beauvais, France

${ }^{4}$ Laboratoire d'Ecologie végétale et Biogéochimie, Université Libre de Bruxelles, 50 Avenue F. Roosevelt, BE-1150 Brussels, Belgium

${ }^{5}$ Ecology, Restoration Ecology and Landscape research Unit, Faculty of Agronomy, University of Lubumbashi, 1825 route Kasapa, Campus universitaire, Lubumbashi, Democratic Republic of Congo

* Claude Grison; E-Mail: claude.grison@cnrs.fr

Tel.: +33-786-854-454

\begin{abstract}
We report the elaboration of novel bio-sourced ecocatalysts for Ullmann coupling reaction. Ecocatalysis is based on the recycling of metals issued from phytoremediation or rehabilitation, and an innovative chemical valorization of the subsequent biomass in the field of catalysis. Here, we describe the efficient copper accumulation by plants via phytoextraction and rhizofiltration. These phytotechnologies were revisited to demonstrate a novel potential of these natural resources for the Green Chemistry. Taking advantage of the remarkable ability of the selected plants to accumulate $\mathrm{Cu}$ (II) species into their roots or leaves, these latter can be directly used for the preparation of ecocatalysts, called Eco- $\mathrm{Cu}^{\circledR}$. The formed $\mathrm{Eco}-\mathrm{Cu}^{\circledR}$ catalysts are thoroughly characterized via ICP-MS, IR study of pyridine sorption/desorption, TEM, XRD, SM and model reactions, in order to elucidate the chemical composition and catalytic activity of these new materials. Significant differences of properties and activities were observed between $\mathrm{Eco}-\mathrm{Cu}^{\circledR}$ and conventional $\mathrm{Cu}$ catalysts. Eco-Cu ${ }^{\circledR}$ appear as highly active catalysts in Ullmann coupling reactions with lower $\mathrm{Cu}$ quantity compared to known copper catalysts.
\end{abstract}

Keywords: phytoextraction; Congolese mining sites; rhizofiltration; contaminated effluents; ecological recycling; ecocatalysis; copper catalysis; Ullmann coupling

\section{Introduction}

Intensive mining and industrial metallurgic activities are responsible for the pollution of soils and aquatic systems with metal trace elements (TEs). This is incredibly worrying, since the soil plays an essential role largely determining food production and water quality. Moreover, TEs are some of the 
most harmful pollutants. They are not biodegradable and persist in organisms and contaminated ecosystems.

For instance, the devastating effects of mining in the southern province of the Democratic Republic of the Congo characterize one of the critical patterns implicated in global environmental change. In Katanga, the negative consequences of mining operations for the local population are clear: large-scale destruction of natural ecosystems and arable soils, severe impacts on hydrological processes, increased sediment pollution in rivers and the groundwater table, reduction of biodiversity, soil erosion, and release of $\mathrm{Cu}$ and $\mathrm{Co}$, which leads to contamination of soils, surface and ground water. Animals are contaminated upon contact, through the inhalation of metal dust, ingestion of contaminated water and food. Metal pollutants travel through the food chain, and thus they have also a significant impact on human health.

Phytoremediation is used to solve environmental problems caused by TEs. Given their phytotoxicity, metalliferous soils are under high selection pressure and generate particular habitats for plant species and their associated microorganisms. This results in a unique biological resource, metallophytes. These plants are defined as being capable of tolerating high concentrations of TEs, surviving and reproducing on such sites ${ }^{1}$. Phytoextraction is one of the few interesting solutions for sustainable phytoremediation of soils degraded or contaminated by TEs. It is defined as the partial rehabilitation of soils through the accumulation of TEs in aerial parts of hyperaccumulator plants (e.g. A. murale ${ }^{2}$, A. vulneraria $^{3}, G$. $\left.e x u l^{4}\right)$. Rhizofiltration is equivalent to phytoextraction process, but it takes place in an aqueous medium instead of the rhizosphere ${ }^{5}$.

However, the development of phytoextraction and rhizofiltration is still restricted because contaminated biomass is not recovered: the aerial parts of hyperaccumulator plants, or roots of plants derived from rhizofiltration are considered as contaminated waste. Moreover, the extraction of TEs by the root system increases the fraction of soluble elements. The sustainability of phytoextraction and rhizofiltration is entirely related to the recycling of the generated biomass.

Our group has recently proposed a unique use and valorization of phytoextraction and rhizofiltration: ecocatalysis $^{6-8}$. Plant waste produced is recovered using an innovative concept of ecological recycling. Taking advantage of the remarkable adaptive capacity of some plants to hyperaccumulate metals, ecocatalysis is based on an original use of metal species of plant origin as reactants and catalysts in fine organic chemical reactions. This allows the preparation of biomolecules using an eco-responsible and bio-inspired approach. The obtained results demonstrate that these new catalytic systems present unique chemical reactivity. Ecocatalysts constitute an entire new generation of Lewis acid catalysts ${ }^{9-15}$, very efficient green oxidative ${ }^{16}$, reductive ${ }^{17}$, and sustainable coupling agents in organic synthesis ${ }^{18}$. They can be used as alternative reagents in place of those prohibited by the European legislation REACH. Finally, we could use these reagents to develop innovative bio-inspired syntheses capable of reducing the environmental impact of implemented procedures.

Ecocatalysis created a change in the paradigm: biomass from phytoextraction and rhizofiltration is no longer considered as contaminated waste, but as a natural restoration system with high added value. This biomass is a natural reservoir of transition metals, precious in organic synthesis. In other words, wastes have become useful and innovative chemical tools.

This article aims at describing new results in the field of phytoremediation of systems contaminated by copper from anthropogenic activities, and to study the recovery of the derived biomass through the 
concept of ecocatalysis. Comparatively, the copper phytoextraction is studied on mining sites in Katanga, while copper rhizofiltration is carried out with contaminated copper solutions. Results clearly allow the preparation, characterization and study of the reactivity of these first Eco-Cu ${ }^{\circledR}$ catalysts in Nand O-arylation coupling reactions.

\section{Results and Discussion}

\subsubsection{Phytoextraction:}

TEs contaminants occurrence and impact on humans and other organisms have already been reported in Katanga (Democratic Republic of the Congo) ${ }^{19}$. Tropical soils contaminated by metal smelters and mining represent a secondary source of contamination with major environmental issue related to low $\mathrm{pH}^{20}$ of Ferralsol increasing TEs mobility, intense erosion by rainfall in the rainy season, and aerial dispersal of metal particles by wind in the dry season. Reduction of environmental risks and TEs dispersion can be performed by phytoremediation, using TEs tolerant and hyperaccumulator plants from the plant biodiversity of natural habitats enriched in $\mathrm{Cu}^{21-23}$. This study is the first investigation on the phytoextraction of soils contaminated by copper smelters and mining associated to the preparation of $\mathrm{Cu}$ ecocatalysts.

\section{Copper concentrations in plant shoots of Anisopappus chinensis}

Mean of $\mathrm{Cu}$ concentration in $A$. chinensis plant shoots (FCu) was $230 \mu \mathrm{g} \mathrm{g}{ }^{-1}$ dry weight (DW) (range: 45-504 $\left.\mu \mathrm{g} \mathrm{g}^{-1} \mathrm{DW}\right)$. The high variation of $\mathrm{Cu}$ accumulation observed in $A$. chinensisis in accordance with previous studies ${ }^{22-24}$. As already highlighted for other $\mathrm{Cu}$-accumulating species, such variations can be genetic, especially due to genetic differentiation within and between populations ${ }^{25}{ }^{26}$. Better understanding of such accumulation variations requires an accurate characterization of the soil-root interface properties and mechanisms controlling $\mathrm{Cu}$ mobility and availability ${ }^{24,27}$. Soil parameters like $\mathrm{pH}$, redox potential, organic matter quality and quantity, oxides, clays, sulphides and carbonates are known to be essential factors controlling TEs mobility in soils ${ }^{28}$. In Congolese metalliferous soils, $\mathrm{Cu}$ is known to be mostly adsorbed by organic matter and iron oxide species ${ }^{20,24}$.

\section{Evaluation of phytoextraction parameters for one year of plant growth}

Mean of shoot biomass of individuals of A. chinensis $(n=20)$ was $1.18 \mathrm{~g}$ (range: 0.14-3.79 g). Biomass productivity (Ybio) was estimated to $17.7 \mathrm{~g} / \mathrm{m}^{2} /$ year whether $177 \mathrm{~kg} /$ ha/year (range: 20-568 $\mathrm{kg} / \mathrm{ha} /$ year). Mean $\mathrm{Cu}$ content in $A$. chinensis plant shoots was $287 \mu \mathrm{g}$ of $\mathrm{Cu}$ per plant from the DW (range: 29-1781 $\mu \mathrm{g}$ plant $^{-1}$ ). A comparable amount of $\mathrm{Cu}$ per plant can be phytoextracted using the $\mathrm{Cu}-$ tolerant species Elsholtzia splendens ${ }^{29,30}$.

Total $\mathrm{Cu}$ phytoextracted $(\mathrm{YCu}=\mathrm{FCu}$. Ybio) $/$ ha/year on contaminated soil using plants of $A$. chinensis from "Mine de l'Etoile" could reach $286 \mathrm{~g} / \mathrm{ha} /$ year. A much more higher yield of phytoextracted $\mathrm{Cu}$ can be obtained with $E$. splendens $\left(1.7 \mathrm{~kg} \mathrm{Cu} \mathrm{ha}^{-1}\right)^{29,30}$, but compared to some crop species, such a yield of phytoextraction could be about five times higher (e.g. sunflower with $\left.59 \mathrm{~g} \mathrm{Cu} \mathrm{ha}^{-1}\right)^{31} . A$. chinensis appears to be a good candidate for $\mathrm{Cu}$ phytoextraction. However, due to the great variability of its ability to extract $\mathrm{Cu}$ from the soil, phytoextraction using $A$. Chinensis should be improved by 
plant selection and genotyping. Indeed, an individual from another natural population could accumulate $\mathrm{Cu}$ up to $1335 \mu \mathrm{g} \mathrm{g}^{-1} \mathrm{DW}$ for $5.1 \mathrm{~g}: 6.7 \mathrm{~g}$ plant $^{-1}$, i.e. a yield almost quadrupled (1 $\mathrm{kg} / \mathrm{ha} /$ year $)^{24}$. Potentially, $\mathrm{Cu}$ phytoextraction might be improved by performing a multispecies system introducing other $\mathrm{Cu}$ tolerant and accumulator species. Such an innovative system on $\mathrm{Cu}$ contaminated soils could lead to an increased phytoextraction yield as some species are known to accumulate $\mathrm{Cu}$ in their shoots more effectively than A. chinensis (e.g. Haumaniastrum robertii) ${ }^{32}$.

This first evaluation on phytoextraction of soils contaminated by $\mathrm{Cu}$ in Tropical Africa has shown a medium yield of $\mathrm{Cu}$ phytoextracted. Perspectives would be to test it at field scale with a multi-species system, introducing functional diversity of $\mathrm{Cu}$-tolerant plants (species and populations).

\subsubsection{Rhizofiltration}

\section{Choice of the plants}

Three plants have been studied to test their ability to accumulate copper into their roots from aqueous medium. Bacopa monnieri was already known to well accumulate copper into its roots ${ }^{5,33}$. Lolium multiflorum was known to accumulate other metallic elements than copper, such as palladium, and its main asset relies on its well-developed root biomass ${ }^{18,34}$. Finally, Eichhornia crassipes was also known to accumulate copper ${ }^{35}$, to multiply easily and also for its amazing root biomass, which of course are assets to perform ecocatalysis.

\section{Plant growth}

Before studying the efficiency of these plants in rhizofiltration, it was interesting to have an insight of the plant biomass growth, and of the biomass measuring (Table 1). The amount of root biomass is important for the removal of copper from aqueous media, and also affects the quantity of ecocatalyst $\left(\mathrm{Eco}-\mathrm{Cu}^{\circledR}\right)$ possibly formed.

B. monnieri and E. crassipes were directly bought in a garden center. L. multiflorum was grown in our laboratory, and the germination percentage after 9 days was $82 \%$.

Table 1. Biomass measuring (mg/plant) for Lolium multiflorum, Bacopa monnieri and Eichhornia crassipes.

\begin{tabular}{|c|c|c|c|c|}
\hline Species & Substrate for growth & $\begin{array}{l}\text { Growth } \\
\text { period }\end{array}$ & $\begin{array}{c}\text { Root } \\
\text { biomass } \\
\text { (mg/plant) }\end{array}$ & $\begin{array}{c}\text { Shoot } \\
\text { biomass } \\
\text { (mg/plant) }\end{array}$ \\
\hline $\begin{array}{c}\text { Lolium } \\
\text { multiflorum }\end{array}$ & $\begin{array}{l}\text { Fleximix Root Riot } \\
\text { Organic Starter Cubes }\end{array}$ & 8 weeks & 6.8 & 20.2 \\
\hline Bacopa monnieri & $\begin{array}{c}\text { Natural substrate } \\
\text { Manado }\end{array}$ & 5 months ${ }^{a}$ & 54 & 840.8 \\
\hline
\end{tabular}




\section{Eichhornia} crassipes

${ }^{\text {a}}$ Period between the start of the cultivation on Manado substrate until the beginning of $\mathrm{Cu}$ accumulation

In terms of root biomass, E. crassipes gave better results than the other plants, which is an asset for copper accumulation, and for ecocatalysts preparation. Moreover, this plant is easy to handle because it can grow without any substrate thanks to its inflated petiole.

Plant analysis: determination of metal concentrations in roots and leaves

Copper concentrations in roots and leaves of the three plants were determined by an ICP-MS analysis. The results are shown in table 2 .

Table 2. Copper concentration in roots and leaves (wt $\% \pm$ standard deviation), and $\mathrm{BCF}$ and $\mathrm{TF}$ calculation.

\begin{tabular}{|c|c|c|c|c|c|c|}
\hline Plant & $\begin{array}{c}\mathrm{Cu} \\
\text { concentration } \\
\text { in effluent } \\
(\mathrm{mg} / \mathrm{L}) \\
\end{array}$ & $\begin{array}{c}\text { Roots } \\
(w t \% \pm \text { SD) }\end{array}$ & $\begin{array}{c}\text { BCF } \\
\text { (in roots) }\end{array}$ & $\begin{array}{c}\text { Leaves } \\
(\mathrm{wt} \% \pm \mathrm{SD})\end{array}$ & $\begin{array}{c}\text { BCF } \\
\text { (in leaves) }\end{array}$ & TF \\
\hline $\begin{array}{c}\text { Bacopa } \\
\text { monnieri }^{a}\end{array}$ & 10.5 & $1.34 \pm 0.011$ & 1279 & $0.097 \pm 0.0011$ & 92 & 0.072 \\
\hline $\begin{array}{c}\text { Lolium } \\
\text { multiflorum }^{b}\end{array}$ & 10.6 & $0.71 \pm 0.0036$ & 666 & $0.0031 \pm 0.000007$ & 2.9 & 0.0044 \\
\hline $\begin{array}{c}\text { Eichhornia } \\
\text { crassipes }^{c}\end{array}$ & 10.5 & $2.55 \pm 0.027$ & 2430 & $\begin{array}{c}0.082 \pm 0.00073 \\
0.19 \pm 0.0014 \\
\text { (petiole) }\end{array}$ & $\begin{array}{c}78 \\
180.4 \\
\text { (petiole) }\end{array}$ & $\begin{array}{c}0.032 \\
0.074 \\
\text { (petiole) }\end{array}$ \\
\hline
\end{tabular}

${ }^{\mathrm{a}}$ During $\mathrm{Cu}$ accumulation the substrate used for growth was removed

${ }^{\mathrm{b}}$ Lolium multiflorum was still on Fleximix Root Riot Organic Starter Cubes during copper accumulation

${ }^{\mathrm{c}}$ No substrate used

Concentration of copper in root biomass is much higher in E. crassipes than in L. multiflorum and B. monnieri. Besides, the translocation factors in the petiole and leaves of E. crassipes remain low, with values between those obtained with $L$. multiflorum and B. monnieri. These results combined with biomass measuring make E. crassipes a good candidate for rhizofiltration to produce ecocatalysts.

\subsubsection{Preparation of the $\mathrm{Eco}-\mathrm{Cu}{ }^{\circledR}$ catalysts}


Eco- $\mathrm{Cu}_{1-2}{ }^{\circledR}$ (A. chinensis), were prepared from harvested plants' leaves and Eco-Cu ${ }_{3-4}{ }^{\circledR}$ (B. monnieri), Eco- $\mathrm{Cu}_{5-6}{ }^{\circledR}$ (L. multiflorum) and Eco-Cu $\mathrm{Cu}_{7-8}{ }^{\circledR}$ (E. crassipes), were prepared from harvested plants' roots following the described procedure (see experimental part, section 3.4.). Each ecocatalyst must be subjected to a heat treatment sufficient to destroy organic matter. Eco-Cu${ }_{2}{ }^{\circledR}, \mathrm{Eco}-\mathrm{Cu}_{4}{ }^{\circledR}, \mathrm{Eco}^{-} \mathrm{Cu}_{6}{ }^{\circledR}$ and Eco- $\mathrm{Cu}_{8}{ }^{\circledR}$ were activated by chemical treatment with hydrochloric acid from Eco-Cu ${ }_{1}{ }^{\circledR}$, Eco-Cu ${ }_{3}{ }^{\circledR}$, Eco$\mathrm{Cu}_{5}{ }^{\circledR}$ and $\mathrm{Eco}-\mathrm{Cu}_{7}{ }^{\circledR}$ respectively. This step enables metal chlorides formation inside of the ecocatalysts.

\subsubsection{ICP-MS characterization of the Eco-Cu ${ }^{\circledR}$}

Table 3 shows mineral composition of the different Eco- $\mathrm{Cu}^{\circledR}$ catalysts. It can be divided in two parts: ecocatalysts derived from phytoextraction $\left(\mathrm{Eco}-\mathrm{Cu}_{1-2}{ }^{\circledR}\right)$ and those obtained from rhizofiltration (Eco$\mathrm{Cu}_{3-8}{ }^{\circledR}$ ). Copper concentrations in Eco-Cu ${ }^{\circledR}$ catalysts are quite different depending on the nature of the plant, which is in agreement with phytoextraction and rhizofiltration studies reported in the previous sections 2.1.1. and 2.1.2. It is clear that ecocatalysts derived from plants used in rhizofiltration are more concentrated in $\mathrm{Cu}$ than ecocatalysts derived from plants used in phytoextraction. For instance, copper concentrations in Eco- $\mathrm{Cu}_{3-4}{ }^{\circledR}$ are 20 times higher than in Eco- $\mathrm{Cu}_{1-2}{ }^{\circledR}$, which confirms that $B$. monnieri is a much better copper accumulator than $A$. chinensis. However, as reported previously (see section 2.1.1. and 2.1.2.), the biomass of A. chinensis is more abundant than the biomass of $B$. monnieri, which is an asset to produce ecocatalysts in larger quantities. E.crassipes is the best plant tested for rhizofiltration, with a weight percentage of copper in its resulting ecocatalyst at least twice higher than in the other ecocatalysts. Moreover, some significant differences between the compositions of the catalysts are observed: $A$. chinensis catalysts are poor in sodium and rich in potassium whereas these rates are reversed in case of $B$. monnieri. In the case of plants used in rhizofiltration, the main difference, apart from the copper rate, is the calcium rate: L. multiflorum is richer in calcium than $E$. crassipes.

Even if the two phytotechnologies, phytoextraction and rhizofiltration, gave different results in terms of accumulation and biomass, they are complementary for the remediation of contaminated targets, soil or water. This article is an opportunity to study the recovery of these different types of biomass through the preparation and the activity of ecocatalysts.

Table 3. Mineral composition of Eco-Cu ${ }^{\circledR}$ catalysts ( $\mathrm{wt} \% \pm$ standard deviation) established by ICPMS.

\begin{tabular}{|c|c|c|c|c|c|c|c|c|c|}
\hline Ecocatalystst & Plant & & & & & & & & \\
\hline \multirow{3}{*}{ Eco-Cu ${ }_{1}{ }^{\circledR}$} & & $\mathrm{Na}$ & $\mathrm{Mg}$ & $\mathrm{Al}$ & K & $\mathrm{Ca}$ & $\mathrm{Fe}$ & $\mathrm{Zn}$ & $\mathrm{Cu}$ \\
\hline & \multirow{4}{*}{ Anisopappus chinensis } & 0.11 & 7.85 & 1.01 & 23.29 & 8.44 & 0.92 & 0.08 & 0.38 \\
\hline & & \pm 4.05 & \pm 0.59 & \pm 3.83 & \pm 4.66 & \pm 1.46 & \pm 0.59 & \pm 1.59 & \pm 0.38 \\
\hline \multirow{2}{*}{$\mathrm{Eco}-\mathrm{Cu}_{2}{ }^{\circledR}$} & & 0.31 & 6.40 & 0.68 & 18.73 & 7.80 & 0.78 & 0.06 & 0.26 \\
\hline & & \pm 1.55 & \pm 0.64 & \pm 0.77 & \pm 0.60 & \pm 0.91 & \pm 0.80 & \pm 0.48 & \pm 0.97 \\
\hline
\end{tabular}




\begin{tabular}{|c|c|c|c|c|c|c|c|c|c|}
\hline \multirow{2}{*}{ Eco- $\mathrm{Cu}_{3}{ }^{\circledR}$} & \multirow{4}{*}{ Bacopa monnieri } & 9.60 & 3.23 & 3.40 & 6.23 & 8.28 & 1.97 & 0.06 & 9.15 \\
\hline & & \pm 0.86 & \pm 0.36 & \pm 0.95 & \pm 0.83 & \pm 0.93 & \pm 0.72 & \pm 1.15 & \pm 0.77 \\
\hline \multirow{2}{*}{ Eco-Cu ${ }_{4}^{\circledR}$} & & 5.29 & 1.86 & 1.93 & 3.48 & 4.91 & 1.21 & 0.04 & 4.75 \\
\hline & & \pm 0.18 & \pm 0.53 & \pm 1.14 & \pm 0.29 & \pm 0.77 & \pm 0.34 & \pm 0.77 & \pm 0.45 \\
\hline \multirow{2}{*}{ Eco-Cu ${ }_{5}^{\circledR}$} & \multirow{4}{*}{ Lolium multiflorum } & 0.78 & 0.60 & 0.00 & 1.11 & 34.61 & 0.04 & 0.09 & 3.29 \\
\hline & & \pm 0.70 & \pm 0.13 & \pm 2.96 & \pm 0.36 & \pm 0.35 & \pm 0.71 & \pm 0.49 & \pm 0.52 \\
\hline \multirow{2}{*}{ Eco-Cu ${ }_{6}^{\circledR}$} & & 0.50 & 0.36 & 0.00 & 0.72 & 22.18 & 0.02 & 0.05 & 2.02 \\
\hline & & \pm 0.69 & \pm 1.48 & \pm 6.00 & \pm 0.71 & \pm 0.59 & \pm 1.86 & \pm 0.72 & \pm 1.05 \\
\hline \multirow{2}{*}{ Eco-Cu ${ }_{7}{ }^{\circledR}$} & \multirow{4}{*}{ Eichhornia crassipes } & 1.26 & 0.43 & 0.13 & 0.38 & 0.97 & 1.85 & 0.06 & 18.15 \\
\hline & & \pm 0.06 & \pm 0.30 & \pm 1.01 & \pm 1.51 & \pm 1.02 & \pm 0.55 & \pm 3.50 & \pm 0.25 \\
\hline \multirow{2}{*}{ Eco-Cu ${ }_{8}{ }^{\circledR}$} & & 0.84 & 0.26 & 0.05 & 0.14 & 0.61 & 0.81 & 0.03 & 10.37 \\
\hline & & \pm 0.57 & \pm 0.95 & \pm 1.82 & \pm 0.34 & \pm 6.97 & \pm 0.21 & \pm 5.86 & \pm 0.23 \\
\hline
\end{tabular}

\subsubsection{XPS Analysis}

XPS analysis was performed on Eco- $\mathrm{Cu}_{8}{ }^{\circledR}$ to study the oxidation state of copper after thermal treatment and activation with $\mathrm{HCl}$.

The strong peak at $202 \pm 0.1 \mathrm{eV}$ corresponding to chlorine $2 p_{3 / 2}$ illustrates the formation of chloride due to the aq. $\mathrm{HCl}$ activation of the material.

High resolution analysis of the copper element was carried out. The $2 p_{3 / 2} \mathrm{Cu}$ signal consists of a combination of two components: 933 and $935 \pm 0.1 \mathrm{eV}$. The more intense one is characterized by a binding energy of $933 \pm 0.1 \mathrm{eV}$, indicating the expected presence of $\mathrm{Cu}(\mathrm{II})$. The component at $935 \pm$ $0.1 \mathrm{eV}$ has a lower intensity (about $13 \%$ of the main peak) and may be assigned to $\mathrm{Cu}(\mathrm{I})$, in agreement with the literature ${ }^{36}$. It is assumed that the observation of $\mathrm{Cu}(\mathrm{I})$ is not due to Eco- $\mathrm{Cu}_{8}{ }^{\circledR}$, because it is well known that $\mathrm{Cu}(\mathrm{II})$ is easily reduced to $\mathrm{Cu}(\mathrm{I})$ when subjected to XPS analysis ${ }^{37}$. Finally, strong $2 p_{3 / 2}$ satellite peaks of $\mathrm{Cu}(\mathrm{II})$ are present in the region of $940-950 \pm 0.1 \mathrm{eV}^{36}$.
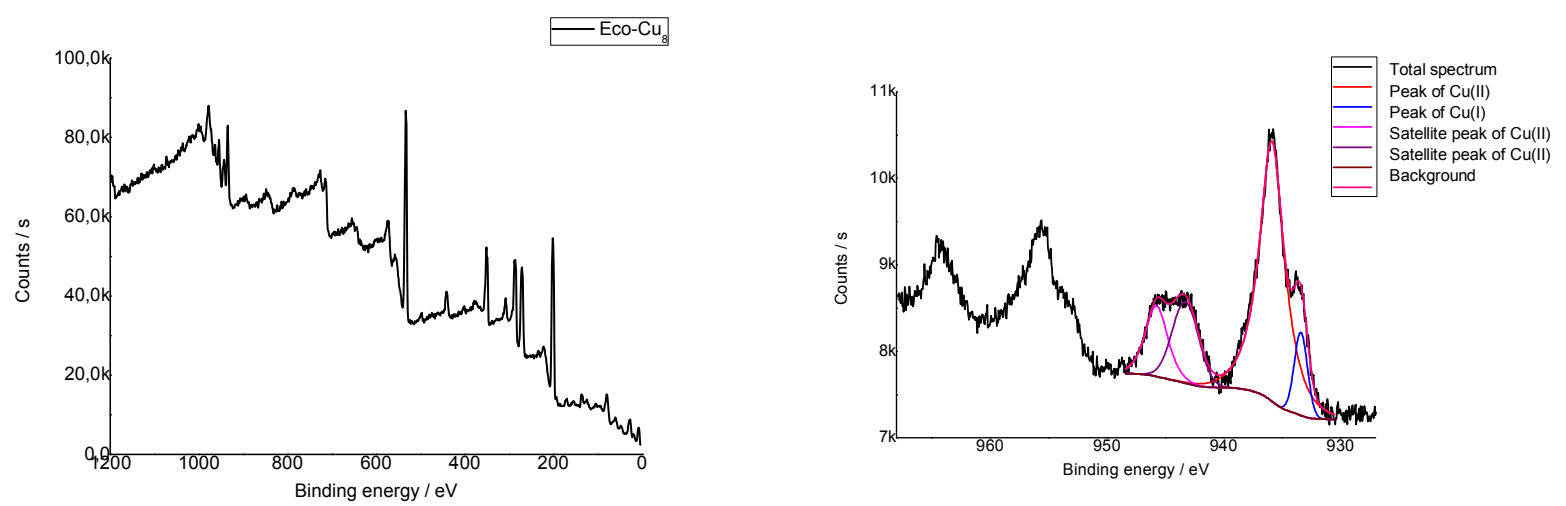

Figure 1. XPS analysis of Eco-Cus ${ }^{\circledR}$

The formation of $\mathrm{Cu}$ (II) is the consequence of an oxidative thermal treatment under air flow of plants' roots. This hypothesis is reinforced by the reaction of Eco- $\mathrm{Cu}_{8}$ with aqueous ammonia and the formation of a deep blue $[\mathrm{Cu}(\mathrm{NH} 3) 4]^{2+}$ complexes. 


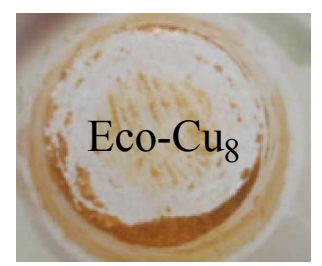
i) $\underset{\mathrm{G} \mathrm{NH}}{\longrightarrow} / \mathrm{H}_{2} \mathrm{O}$
ii) vortexing

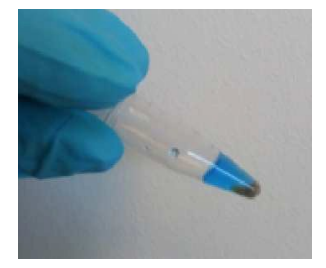

Figure 2. Analytical characterization of $\mathrm{Eco}-\mathrm{Cu}_{8}{ }^{\circledR}$

In the aim to specify the nature of copper (II) chloride salts, mass spectrometry analysis were performed by direct-injection mass spectrometric method.

\subsubsection{Direct-injection mass spectrometric analysis}

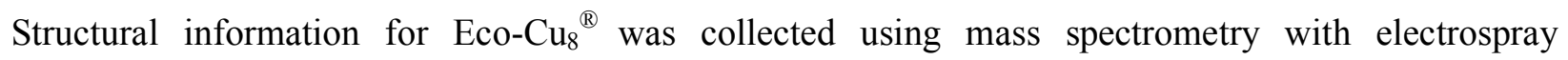
ionization operated in the negative ion mode. This MS method provided sufficient sensitivity and selectivity for the rapid identification of an anionic inorganic species, but it led to the electrochemical reduction of $\mathrm{Cu}(\mathrm{II})$ into $\mathrm{Cu}(\mathrm{I})$ according to Gianelli works ${ }^{38}$.

With Eco- $\mathrm{Cu}_{8}{ }^{\circledR}$, two $\mathrm{Cu}$ chlorides species were detected: $\mathrm{CuCl}_{3}{ }^{2-}$ and $\mathrm{CuCl}_{2}{ }^{-}$. Taking into account the copper oxidation state reduction of $\mathrm{Cu}$ by the ESI method, we can conclude that Eco-Cu ${ }_{8}{ }^{\circledR}$ consists of a mixture of $\mathrm{CuCl}_{4}{ }^{2-}$ and $\mathrm{CuCl}_{3}$ - This hypothesis is consistent with the XPS analysis.

\subsubsection{XRD studies}

XRD analyses of Eco- $\mathrm{Cu}_{8}{ }^{\circledR}$ were performed in order to determine the crystalline structure of the complexes in the catalyst (Figure 3 ). One polymetallic compound was detected: $\mathrm{K}_{6} \mathrm{Fe}_{2} \mathrm{O}_{5}$. Manganese was present in the manganosite form $\mathrm{MnO}$, in the presence of sodium chloride and calcium sulfate hydrate. Copper was present in the amorphous form.

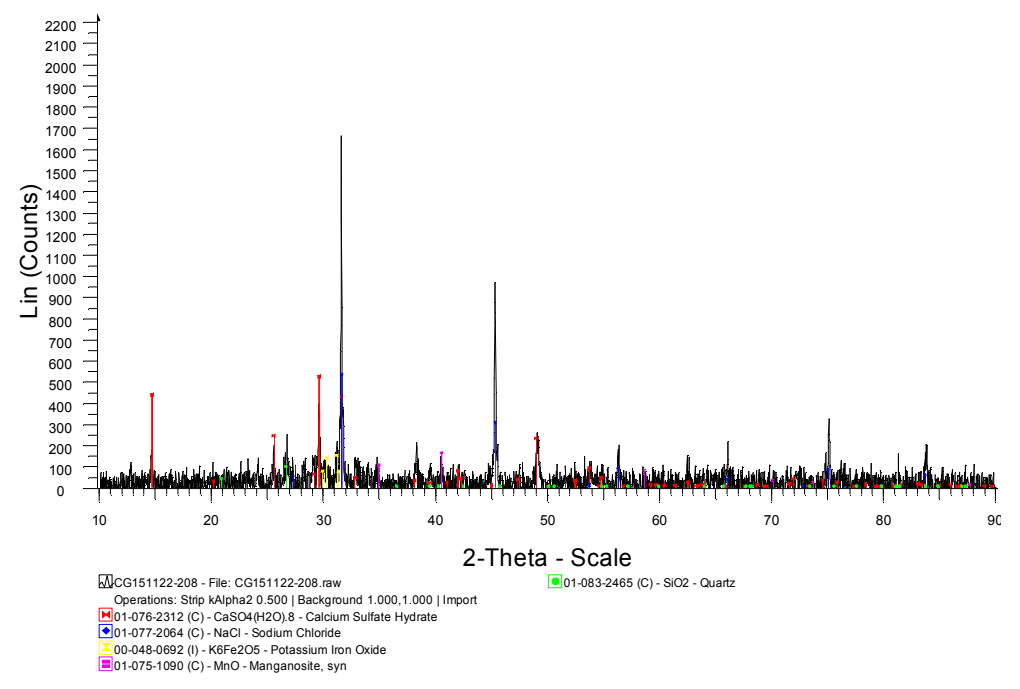

Figure 3. XRD analysis of Eco-Cus ${ }^{\circledR}$ 


\subsubsection{TEM studies}

The morphology and structure of Eco-Cu ${ }_{8}{ }^{\circledR}$ was further characterized using TEM. Figures $4 \mathrm{a}$ and $4 \mathrm{~b}$ shows the TEM images. The microstructure of the ecocatalyst is layered with dark shades and clear areas, indicating a satisfactory uniformity in the composition of the ecocatalyst. TEM images of Eco$\mathrm{Cu}_{8}{ }^{\circledR}$ in figure $4 \mathrm{~b}$ reveal $\mathrm{Cu}$ nanoparticles, which are embedded in the solid matrix. These nanoparticles are not aggregated and are well dispersed at the surface of the matrix. The particle size has been determined based on the average size of 40 particles. The particles show a relatively narrow size distribution centered around 4-8 $\mathrm{nm}$.
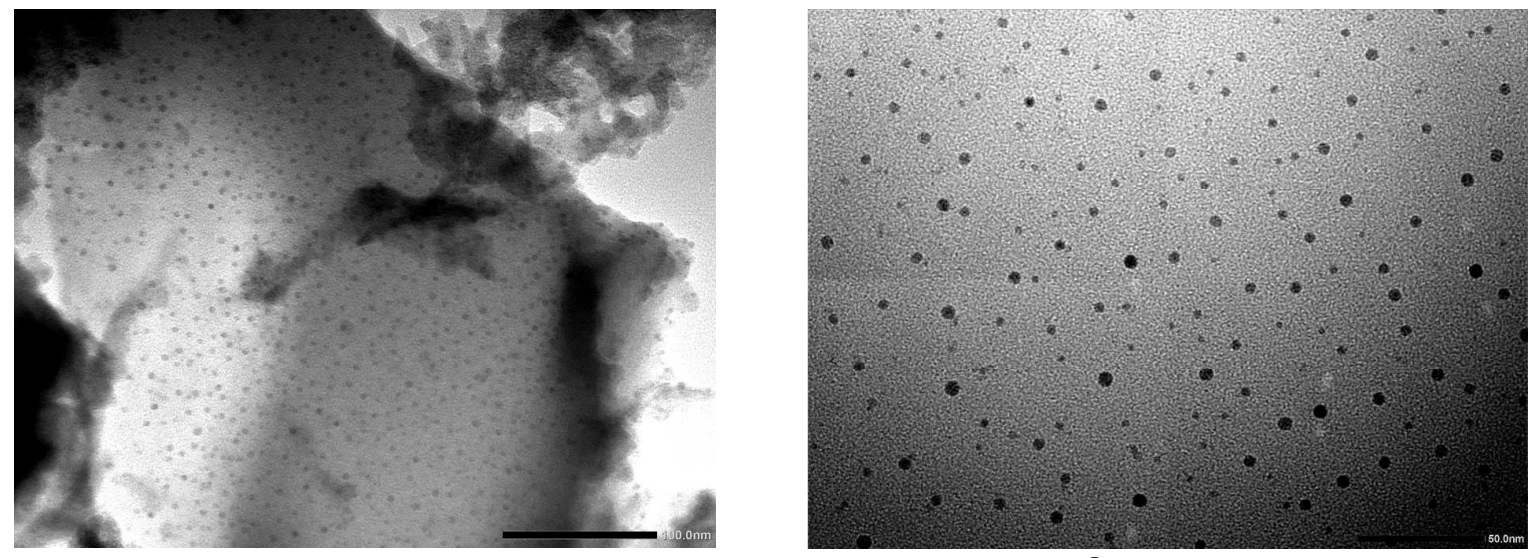

Figures 4a and4b. TEM images of Eco- $\mathrm{Cu}_{8}{ }^{\circledR}$

\subsubsection{Acidity characterization of the Eco-Cu ${ }^{\circledR}$ catalyst}

We decided to study Lewis and Brønsted acid properties of our best ecocatalyst (Eco-Cu ${ }_{8}{ }^{\circledR}$, see 2.3 section) versus commercial copper chlorides. Lewis acidity is usually defined by its strength and its hardness according to the HSAB principle, described by Pearson ${ }^{39,40}$. Two conventional methods were used: the first one is based on the infrared study of pyridine adsorption/desorption on the catalysts. The second, introduced by Corma et al. consists in studying the rearrangement of a cyclic acetal. The first method enables a comparison of the Lewis acid strength and Brønsted acidity between different catalysts. The method implemented by Corma et al. enables also a comparison of the hardness of Lewis acidity.

Pyridine is often used as a probe to evaluate Lewis and Brønsted acidity of solid acids ${ }^{41,42}$ by monitoring its infrared absorption bands between 1400 and $1660 \mathrm{~cm}^{-1}$. Infrared spectra of pyridine adsorbed on Eco- $\mathrm{Cu}_{8}{ }^{\circledR}$, on commercial anhydrous $\mathrm{CuCl}_{2}$, and on $\mathrm{CuCl}_{2} \cdot 2 \mathrm{H}_{2} \mathrm{O}$ were recorded at $23^{\circ} \mathrm{C}$ and at $150^{\circ} \mathrm{C}$ in order to distinguish physisorbed pyridine from pyridine coordinately bonded to Lewis acid sites. The absorption bands around $1450 \mathrm{~cm}^{-1}$ observed on the spectra are characteristic of strongly bonded pyridine to Lewis acid sites ${ }^{41,42}$ (Figure 5). Because the frequencies of these absorption bands were similar in the three catalysts, we can conclude that the strength of the Lewis acidity is not really different between Eco- $\mathrm{Cu}_{8}{ }^{\circledR}$, anhydrous $\mathrm{CuCl}_{2}$ and $\mathrm{CuCl}_{2} \cdot 2 \mathrm{H}_{2} \mathrm{O}$. Besides, two 
absorption bands, characteristic of pyridinium ion, were observed at 1530 and $1537 \mathrm{~cm}^{-1} 42$ with Eco$\mathrm{Cu}_{8}{ }^{\circledR}$ only. Thus Eco-Cu${ }_{8}{ }^{\circledR}$ present a Brønsted acidity contrary to both commercial copper chlorides.

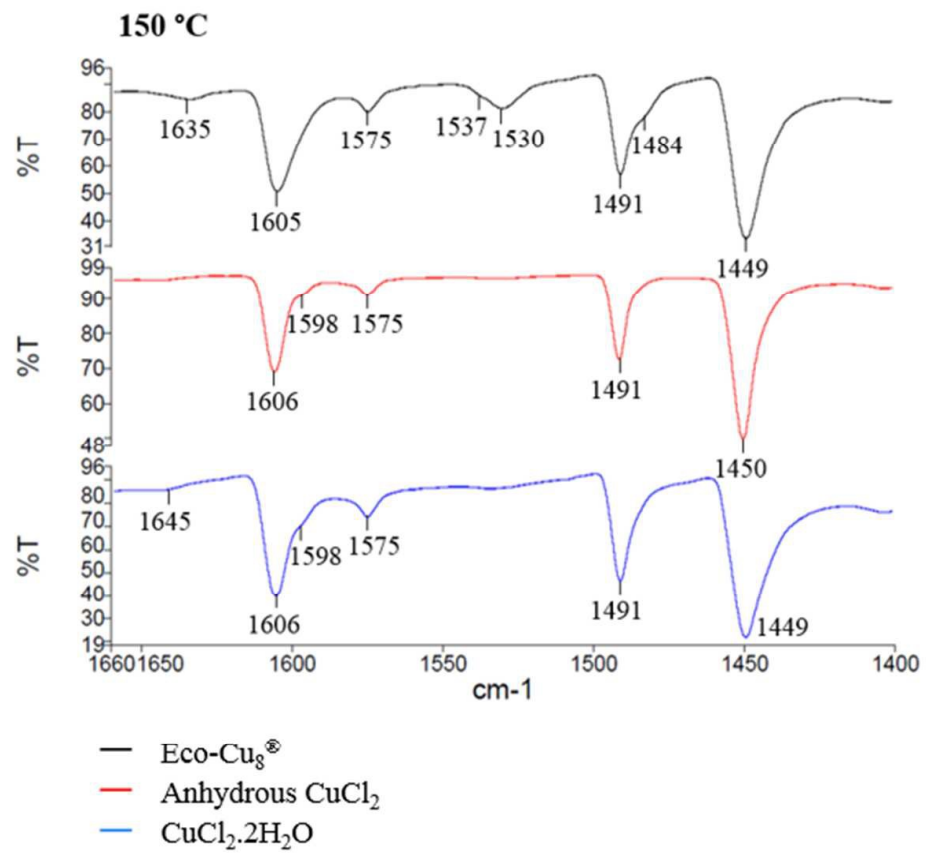

Figure 5. IR spectra of pyridine adsorbed on Eco- $\mathrm{Cu}_{8}{ }^{\circledR}$, on commercial anhydrous $\mathrm{CuCl}_{2}$ and $\mathrm{CuCl}_{2} \cdot 2 \mathrm{H}_{2} \mathrm{O}$.

These first conclusions were completed and supported by another method, implemented and tested by Corma et al. ${ }^{43,44}$. This method consists in studying the rearrangement pathway of the cyclic acetal of $\alpha$-bromopropiophenone, in the presence of a catalyst. The selectivity of products formed during the reaction provides informations to assess the hardness of the Lewis acid sites of the catalysts. It can also highlight their Brønsted acid property. The selectivity results obtained are presented in Table 4 . The Brønsted acid pathway is slightly stronger in Eco- $\mathrm{Cu}_{8}{ }^{\circledR}$ than in both commercial copper chlorides, which supports the previous infrared study of adsorbed pyridine. According to conversion rates, Eco$\mathrm{Cu}_{8}{ }^{\circledR}$ is more active on cyclic acetal than both commercial copper chlorides, which might result from its stronger Brønsted acid character. Finally, the product from the soft Lewis acid pathway is only formed with commercial copper chlorides but not with Eco-Cu ${ }_{8}^{\circledR}$. Therefore, the Lewis acidity of Eco$\mathrm{Cu}_{8}{ }^{\circledR}$ is harder than the Lewis acidity of commercial copper chlorides, which might be due to the presence of other elements known to be hard Lewis acids ${ }^{45}$, such as iron or calcium as shown by the ICP-MS analysis (Table 3).

Table 4. Conversion rates and selectivities of products coming from the rearrangement of cyclic acetal of $\alpha$-bromopropiophenone with Eco- $\mathrm{Cu}_{8}{ }^{\circledR}$ and commercial anhydrous $\mathrm{CuCl}_{2}$ and $\mathrm{CuCl}_{2} \cdot 2 \mathrm{H}_{2} \mathrm{O}$. 


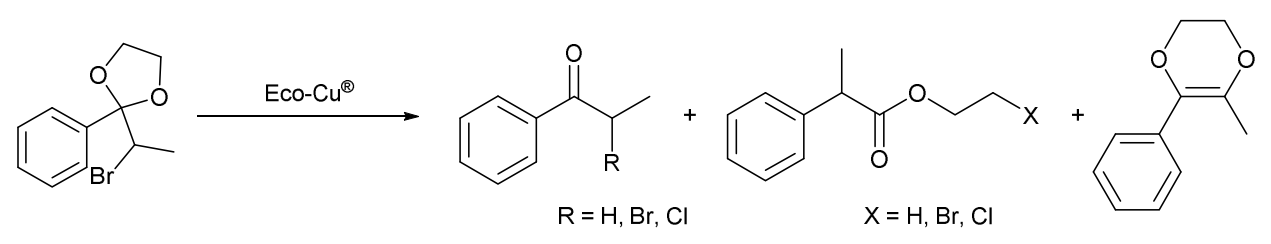
Catalysts
Conversion
Selectivity $^{a}[\%]$

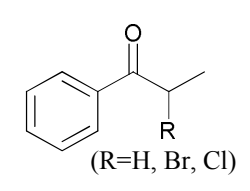

Brønsted acidity

products

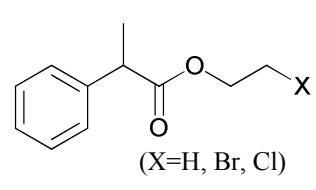

Hard Lewis acidity products

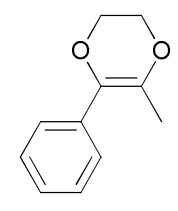

Soft Lewis acidity product

\begin{tabular}{lcccc} 
Eco- $^{-\mathrm{Cu}_{8}{ }^{\circledR}}$ & 100 & 64 & 36 & 0 \\
Anhydrous $\mathrm{CuCl}_{2}$ & 49 & 52 & 41 & 7 \\
$\mathrm{CuCl}_{2} \cdot 2 \mathrm{H}_{2} \mathrm{O}$ & 65 & 39 & 58 & 3 \\
\hline
\end{tabular}

${ }^{a}$ Determined by GC-MS analysis

\subsection{Reactivity of Eco-Cu ${ }^{\circledR}$ in Ullmann coupling reaction}

Copper was the first metal used in cross-coupling reactions ${ }^{46,47}$ decades before palladium- and nickelcatalyzed procedures had emerged. Copper has the advantage of being inexpensive, earth-abundant, non-toxic and then found in widespread applications in homogeneous chemical catalysis. Indeed for more than a century, copper is an effective catalyst for the useful and practical formation of C(aryl)-N, $\mathrm{C}$ (aryl)-C, and $\mathrm{C}(\operatorname{aryl})-\mathrm{O}$ bonds ${ }^{48-50}$. Such copper-mediated coupling reactions have numerous industrial applications, including the synthesis of intermediates as well as synthetic targets for the life sciences, agrochemical and polymer industries ${ }^{51,52}$. However, Ullmann-type coupling reactions have been neglected for a long time because of their drawbacks: harsh reaction conditions often used, limited range of suitable substrates and moderate yields obtained. These condensations are usually conducted in aprotic polar solvents such as N-methylpyrrolidone or N,N-Dimethylformamide at high temperature, with copper reagent rarely used in catalytic quantities. Therefore important efforts are provided among the community of organic chemists to discover new milder, inexpensive and environmentally benign reaction conditions. Recently, several research groups obtained interesting results in producing inexpensive copper catalysts complexed with simple ligands ${ }^{53}$, able to perform economical and efficient $\mathrm{N}$-arylation of nitrogen-containing heterocycles with aryl halides. These ligands derived from phosphines ${ }^{54}$, amino $\operatorname{acids}^{55}, \beta$-diketones $^{56}$ or 1,2-diamines ${ }^{57}$, 58. They are important to improve both the catalyst concentration and its electronic density. With these ligands, the coupling reactions are more efficient, but this implies increasing cost, bad ecological footprint and contamination of the final product. The past few years, to circumvent those inconveniences, ligand- 
free Ullmann coupling have been performed using $\mathrm{CuI}$ and $\mathrm{Cu}_{2} \mathrm{O}$ as catalysts with good results. Indeed Ullmann-type coupling reaction can be catalyzed by all copper species from $\mathrm{Cu}(\mathrm{I})$ to $\mathrm{Cu}(\mathrm{II})$ and even by metal copper since the original work of Ullmann and Goldberg $46,47,59,60$. In 1928, Weston et al. published results concerning the Ullmann reaction comparing a wide range of catalyst sources, leading them to say that: "almost any copper or copper compound may be used as a source of catalyst", although $\mathrm{Cu}(\mathrm{I})$ salts appeared to give better results. In fact, it has been demonstrated later by analytical meanings that the active species is the cuprous salt $\left(\mathrm{Cu}^{+}\right)$which if not directly introduced, can be generated by in situ reduction of $\mathrm{Cu}$ (II) or oxidation of $\mathrm{Cu}(0)^{61-64}$. Besides it is known that common nitrogen heterocycles such as phtalimide, pyrrole, imidazole and pyrazole derivatives are more reactive in Ullmann coupling ${ }^{65-68}$. In spite of the significant progress, more efficient, air or/and moisture-stable and easy-synthesized ligands are still in demand, in order to facilitate these coupling reactions under relatively mild conditions. The copper-mediated Ullmann reaction still suffers from required drastic reaction conditions: ligands and large amount of $\mathrm{Cu}$ are necessary for successful coupling reactions. From these observations, and regarding the efficiency of palladium ecocatalsysts (Eco-Pd ${ }^{\mathbb{B}}$ ) developed in our laboratory in cross-coupling reactions ${ }^{18}$, the catalytic potential of $\mathrm{Eco}-\mathrm{Cu}^{\circledR}$ should be investigated.

\subsubsection{Results}

With regard to the unusual acid properties of the $\mathrm{Eco}-\mathrm{Cu}^{\circledR}$, it was interesting to study their reactivity in arylation of amines and alcohols. The Lewis acidity of Eco-Cu ${ }^{\circledR}$ was an interesting parameter to modulate the reactivity of nucleophiles, and to activate the halide partners during the oxidative addition step.

The first part of this work is a comparative study of the different Eco-Cu ${ }^{\circledR}$ catalysts on a model coupling reaction. It is known that common nitrogen heterocycles such as phtalimide, pyrrole, imidazole and pyrazole derivatives are particularly reactive in the Ullmann coupling reaction ${ }^{65-68}$. Thus, the model $\mathrm{N}$-arylation was performed with pyrazole and iodobenzene, using the conditions described by Taillefer et al. ${ }^{65}$ who developed one of the few examples of bimetallic catalysis ${ }^{69,} 70$. Cesium carbonate was chosen to avoid the use of strong bases, as described by the group of Buchwald $^{71}$ in diaryl ether synthesis. Many different copper salts and oxides have been used to catalyze Ullmann-type reactions. These results suggested that each Eco- $\mathrm{Cu}^{\circledR}$ could be efficient in the reaction. However we observed that $\mathrm{Eco}-\mathrm{Cu}^{\circledR}$ activated by $\mathrm{HCl}\left(\mathrm{Eco}_{-} \mathrm{Cu}_{2}{ }^{\circledR}, \mathrm{Eco}^{-\mathrm{Cu}_{4}}{ }^{\circledR}, \mathrm{Eco}^{-\mathrm{Cu}_{6}}{ }^{\circledR}\right.$ and Eco- $\left.\mathrm{Cu}_{8}{ }^{\circledR}\right)$ are much more efficient than Eco-Cu ${ }^{\circledR}$ solely thermally treated $\left(\mathrm{Eco}-\mathrm{Cu}_{1}{ }^{\circledR}\right.$, Eco-Cu${ }_{3}{ }^{\circledR}$, Eco$\mathrm{Cu}_{5}{ }^{\circledR}$, and Eco- $\mathrm{Cu}_{7}{ }^{\circledR}$ ) (Table 5). Then, we observed a direct correlation between coupling efficiency and copper concentration inside the catalyst, which is an essential observation concerning the recovery of biomass obtained via phytoextraction or rhizofiltration technics. Indeed, although Eco-Cu ${ }^{\circledR}$, Eco$\mathrm{Cu}_{6}{ }^{\circledR}$ and Eco-Cu ${ }_{8}{ }^{\circledR}$ give similar good conversion rates with copper concentrations from 2 to 10 percent by weight (Table 5), Eco- $\mathrm{Cu}_{2}{ }^{\circledR}$ with only 0.26 percent by weight of copper, has shown a much lower conversion rate.

Moreover, with most of the ecocatalysts, we managed to get good yields with only $1 \mathrm{~mol} \%$ of copper, which is a very low catalytic loading compared to studies described in previous literature (10-20 mol\% $)^{72-74}$. Using small amounts of catalyst is a significant advantage for this type of C-N coupling 
reaction, both for practical, environmental and economic reasons. Thus, we attempted to optimize the catalyst amount using the most active ecocatalyst, Eco- $\mathrm{Cu}_{8}{ }^{\circledR}$, (entries 8, 9, 10). The coupling reaction was still possible with $0.25 \mathrm{~mol} \%$ of copper (entry 10). Surprisingly, increasing the catalyst amount did not improve the conversion rate (entry 9). As the results show, the catalytic loading of $1 \mathrm{~mol} \%$ is a very good compromise between catalyst economy and chemical efficiency. It is important to mention that similar reactions under ligand-free conditions, described in literature, require a considerably higher loading of copper sources and more drastic reaction conditions e.g. $20 \mathrm{~mol} \%$, $8 \mathrm{~h}$ at $120^{\circ} \mathrm{C}$ in nPrCNas described by $\mathrm{Hu}$ an coworkers ${ }^{75}$, or $10 \mathrm{~mol} \%$, 24h at $120^{\circ} \mathrm{C}$ in DMF as described by Zhang et al. $^{74}$. In comparison, the same authors reported that the $\mathrm{N}$-arylation of pyrazole with iodobenzene using an excess of tetraethylenepentamine (TEPA) (2 equiv.), as a base, and $10 \mathrm{~mol} \%$ of copper source were still necessary, TBAB $(0.3$ equiv. $)$ and reaction time of $12 \mathrm{~h}$ at $125^{\circ} \mathrm{C}^{76}$. The loading of copper could be reduced to $5 \mathrm{~mol} \%$. However, if the amount of copper is reduced, then use of unusual copper sources such as $\mathrm{CuO}$ hollow nanospheres immobilized onto acetylene black ${ }^{77}$, or $\mathrm{Cu}_{2} \mathrm{O}$ coated $\mathrm{Cu}$ nanoparticles $^{78}$, must be used. Unfortunately, both protocols require harsh reaction conditions, $18 \mathrm{~h}$ at $180^{\circ} \mathrm{C}$ and $18 \mathrm{~h}$ at $150^{\circ} \mathrm{C}$, respectively. Finally the loading of copper sources of $0.08 \mathrm{~mol} \%$ for the Narylation of pyrazole with iodobenzene under ligand-free-like conditions was reported by Bolmet. al. ${ }^{79}$. However the reaction described requires the presence of DMEDA (20 mol\%). It was carried out at $135^{\circ} \mathrm{C}$ for $24 \mathrm{~h}$ and authors did not test other aryl halides, thus the scope of the reaction remains unknown. It can be concluded therefore, that the use of Eco-Cu ${ }^{\circledR}$ catalysts represents a clear advantage over the literature protocols.

Finally, the results obtained with the use of Eco-Cu ${ }^{\circledR}$ catalysts can also be advantageously compared to commercial $\mathrm{Cu}$ catalysts, such as $\mathrm{CuCl}_{2}, \mathrm{CuCl}$ and $\mathrm{CuO}$ (entries 11, 12, 13and 14). Commercial $\mathrm{CuO}$ exhibited poor activity in the conditions used. Commercial $\mathrm{CuCl}_{2}$ and $\mathrm{CuCl}$ promoted the reaction, but conversion rates were lower than those obtained with Eco- $\mathrm{Cu}_{8}{ }^{\circledR}$. These results demonstrated the performance of Eco-Cu ${ }^{\circledR}$.

Table 5. Screening of Eco- $\mathrm{Cu}^{\circledR}$ using fixed reaction conditions.

\begin{tabular}{|c|c|c|c|c|}
\hline Entry $^{\mathrm{a}}$ & Eco-Cu ${ }^{\circledR}$ catalyst & $\mathrm{Cu}$ in catalyst (wt. \%) & $\mathrm{Cu}$ quantity $(\mathrm{mol} \%)$ & Yields $(\%)^{\mathrm{b}}$ \\
\hline 1 & Eco- $\mathrm{Cu}_{1}{ }^{(B)}$ & 0.38 & 1 & $25^{\mathrm{c}}$ \\
\hline 2 & $\mathrm{Eco}-\mathrm{Cu}_{2}{ }^{(B)}$ & 0.26 & 1 & $37^{\mathrm{c}}$ \\
\hline 3 & $\mathrm{Eco}-\mathrm{Cu}_{3}{ }^{(B)}$ & 9.1 & 1 & $18^{\mathrm{c}}$ \\
\hline 4 & Eco- $\mathrm{Cu}_{4}{ }^{(B)}$ & 4.8 & 1 & 84 \\
\hline 5 & $\mathrm{Eco}^{-\mathrm{Cu}_{5}}{ }^{(\mathbb{R})}$ & 3.3 & 1 & $11^{\mathrm{c}}$ \\
\hline 6 & $\mathrm{Eco}^{-\mathrm{Cu}_{6}}{ }^{(\mathbb{R})}$ & 2.0 & 1 & 77 \\
\hline 7 & $\mathrm{Eco}^{-\mathrm{Cu}_{7}}{ }^{(\mathbb{R})}$ & 18 & 1 & 66 \\
\hline
\end{tabular}




\begin{tabular}{|c|c|c|c|c|}
\hline 8 & Eco-Cu ${ }_{8}^{\circledR}$ & 10 & 1 & 85 \\
\hline 9 & $\mathrm{Eco}-\mathrm{Cu}_{8}{ }^{\circledR}$ & 10 & 4 & 83 \\
\hline 10 & $\mathrm{Eco}^{-\mathrm{Cu}_{8}}{ }^{(\mathbb{R}}$ & 10 & 0.25 & 57 \\
\hline 11 & $\mathrm{CuCl}_{2}$ & - & 1 & $48^{\mathrm{c}}$ \\
\hline 12 & $\mathrm{CuCl}_{2}$ & - & 3 & $79^{c}$ \\
\hline 13 & $\mathrm{CuCl}$ & - & 1 & $76^{\mathrm{c}}$ \\
\hline 14 & $\mathrm{CuO}$ & - & 1 & $9^{c}$ \\
\hline
\end{tabular}

${ }^{\mathrm{a}}$ Reaction conditions: iodobenzene $(5 \mathrm{mmol})$, pyrazole $(7.5 \mathrm{mmol}), \mathrm{Eco}-\mathrm{Cu}^{\circledR}(50 \mu \mathrm{mol}), \mathrm{Cs}_{2} \mathrm{CO}_{3}(10 \mathrm{mmol}), \mathrm{DMF}(5 \mathrm{~mL})$, $90{ }^{\circ} \mathrm{C}, 15 \mathrm{~h}$, argon atmosphere

${ }^{\mathrm{b}}$ Isolated yields

${ }^{\mathrm{c}}$ Yields were determined by GC-MS analysis

Eco- $\mathrm{Cu}_{8}{ }^{\circledR}$ appears as a highly active catalyst in $\mathrm{N}$-arylation reaction without ligands and additives, which represents a valuable alternative compared to classical catalytic systems used in literature. Moreover, the reaction requires a considerably low quantity of $\mathrm{Cu}(1 \mathrm{~mol} \%)$. This is important in light of the need to lower the residual copper levels in the product after work-up, especially in the case of pharmaceutical synthesis.

The very good performance of Eco- $\mathrm{Cu}_{8}{ }^{\circledR}$ could be partially explained by its polymetallic composition, and more precisely by the presence of alkaline metals, as highlighted by ICP-MS analysis (see section 2.2.2). Indeed, Zhang et al. ${ }^{80}$, have demonstrated the benefits of inorganic salt particles in transition metal-catalyzed coupling reactions. The partial negative charges on the salt surface create an electrondonating effect, which increases the electron density of the metal center. Besides, the anions at the surface of the solid salt particles have a similar influence on the aryl halide. The combination of these effects promotes the oxidative addition step and enhances the reaction rate.

Furthermore, Fan et al. have described the activity of several Lewis acids to assist the polarization of the aryl-halogen bond. Significant rate-enhancement has been reported by addition of catalytic amounts of Lewis acids during transition metal-catalyzed cross coupling reactions ${ }^{81,82}$. As metallic elements highlighted by ICP-MS analysis in Eco- $\mathrm{Cu}_{8}{ }^{\circledR}$ are Lewis acids, they might thus promote the reaction.

Finally, these results are consistent with our previous work on Heck-Mizoroki and Suzuki-Miyaura cross coupling reactions with Eco- $\mathrm{Pd}^{\circledR}$ catalysts $^{18}$, characterized by an excellent dispersion of active centers on the saline matrix.

After this first screening of different Eco- $\mathrm{Cu}^{\circledR}$ catalysts, the methodology has been extended to different amines, by using the most active catalyst, Eco- $\mathrm{Cu}_{8}{ }^{\circledR}$, with $\mathrm{Cs}_{2} \mathrm{CO}_{3}$ at $90^{\circ} \mathrm{C}$. As shown in Table 6, azole derivatives are the most reactive substrates, whereas no conversion rate was observed with aniline. Besides, low conversion rates were obtained with secondary amines such as pyrrolidine and morpholine (entries 5 and 6).

Table 6. Screening of amines using fixed reaction conditions. 


\begin{tabular}{|c|c|c|c|c|}
\hline Entry $^{\mathrm{a}}$ & Nucleophile & Yield $(\%)^{b}$ & & GC/MS spectral data ${ }^{\mathrm{d}}$ \\
\hline 1 & pyrazole & 85 & & $\begin{array}{l}\mathrm{rt}=11.63 \mathrm{~min} \\
\mathrm{~m} / \mathrm{z}=144(51,77,90,117)\end{array}$ \\
\hline 2 & imidazole & 54 & & $\begin{array}{l}\mathrm{rt}=12.76 \mathrm{~min} \\
\mathrm{~m} / \mathrm{z}=144(51,77,90,117)\end{array}$ \\
\hline 3 & 2-pyrrolidone & $31^{\mathrm{c}}$ & & \\
\hline 4 & aniline & $0^{\mathrm{c}}$ & & \\
\hline 7 & pyrrolidine & $6^{\mathrm{c}}$ & & \\
\hline 8 & morpholine & $5^{\mathrm{c}}$ & & \\
\hline
\end{tabular}

${ }^{\mathrm{a}}$ Reaction conditions: iodobenzene $(5 \mathrm{mmol})$, nucleophile $(7.5 \mathrm{mmol}), \mathrm{Eco}-\mathrm{Cu}_{8}{ }^{\circledR}(50 \mu \mathrm{mol}), \mathrm{Cs}_{2} \mathrm{CO}_{3}(10 \mathrm{mmol}), \mathrm{DMF}(5$ $\mathrm{mL}), 90^{\circ} \mathrm{C}, 15 \mathrm{~h}$, argon atmosphere

${ }^{\mathrm{b}}$ Isolated yields

${ }^{\mathrm{c}}$ Yields were determined by GC-MS analysis

${ }^{\mathrm{d}}$ All compounds synthetized were fully characterized and found to be in agreement with the literature data. GC retention time and mass spectrometry (EI) data are given.

After those preliminary results, our efforts have been focused on pyrazole as nucleophile for Ullmann condensation. Numerous aryl halides substituted with various electron-withdrawing and -donating groups were investigated (Table 7) at different temperatures, with $\mathrm{Cs}_{2} \mathrm{CO}_{3}$ as base, $1 \mathrm{~mol} \%$ of catalytic charge and without ligands. The Ullmann reaction required DMF as solvent. Indeed water, toluene and $\gamma$-valerolactone were tested as green solvents ${ }^{83}$ but the reaction did not occur, except in $\gamma$-valerolactone with limited conversion rate (results not shown). The usual influence of the nature of the halide in coupling reactions was respected (entries 1, 5 and 9). Eco- $\mathrm{Cu}_{8}{ }^{\circledR}$ was efficient in cross-coupling reactions with aryl iodides, aryl bromides and even aryl chlorides. The use of aryl chlorides in Ullmann type reactions is especially desirable to industries, because they are often less expensive than iodides and bromides, thus their use has a real economic advantage ${ }^{84}$.

Tertiary amines were formed in good to excellent yields if temperature was adjusted. Noteworthy, the coupling reaction of pyrazole was sensitive to electronic effects of substituents on aryl halides partners. The presence of $p$-OMe electron-donating substituent clearly diminished the efficiency of the reaction. This could be counter balanced by a moderate elevation of the reaction temperature (entries 1, 2 and 3 ) from 90 to $110^{\circ} \mathrm{C}$. Finally, electron-withdrawing groups facilitated the coupling reaction depending on the electronegativity of the groups (entries 4-9). Thus, the reaction was quantitative in $4 \mathrm{~h}$ at $90^{\circ} \mathrm{C}$ using iodoacetophenone (entry 4).

Table 7. Aryl halides and temperature conditions screening. 


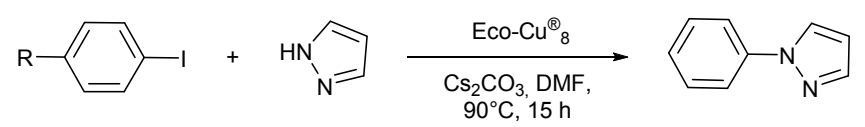

\begin{tabular}{|c|c|c|c|c|c|}
\hline Entry $^{a}$ & Aryl halide & $\mathrm{T}^{\circ} \mathrm{C}$ & Time (h) & Yield $(\%)^{b}$ & GC/MS spectral data ${ }^{\mathrm{d}}$ \\
\hline 1 & & 90 & 15 & 85 & $\begin{array}{l}\mathrm{rt}=11.63 \mathrm{~min} \\
\mathrm{~m} / \mathrm{z}=144(51,77,90,117)\end{array}$ \\
\hline 2 & & 90 & 15 & $63^{c}$ & $\begin{array}{l}\mathrm{rt}=13.97 \mathrm{~min} \\
\mathrm{~m} / \mathrm{z}=174(77,131,159)\end{array}$ \\
\hline 3 & & 110 & 15 & 93 & \\
\hline 4 & & 90 & 4 & $>98$ & $\begin{array}{l}\mathrm{rt}=15.31 \mathrm{~min} \\
\mathrm{~m} / \mathrm{z}=186(89,116,143,171)\end{array}$ \\
\hline 5 & & 90 & 15 & $31^{\mathrm{c}}$ & \\
\hline 6 & & 90 & 4 & $>98$ & $\begin{array}{l}\mathrm{rt}=15.55 \mathrm{~min}, \\
\mathrm{~m} / \mathrm{z}=189(65,89,116,131, \\
159)\end{array}$ \\
\hline 7 & & 90 & 4 & $>98$ & \\
\hline 8 & & 90 & 15 & 73 & $\begin{array}{l}\mathrm{rt}=14.61 \mathrm{~min} \\
\mathrm{~m} / \mathrm{z}=169(75,102,115,142)\end{array}$ \\
\hline 9 & & 110 & 15 & 89 & \\
\hline
\end{tabular}

${ }^{\mathrm{a}}$ Reaction conditions: Aryl halide $(5 \mathrm{mmol})$, pyrazole $(7.5 \mathrm{mmol}), \mathrm{Eco}_{-} \mathrm{Cu}_{8}{ }^{\circledR}(50 \mu \mathrm{mol}), \mathrm{Cs}_{2} \mathrm{CO}_{3}(10 \mathrm{mmol}), \mathrm{DMF}(5 \mathrm{~mL})$, argon atmosphere

${ }^{\mathrm{b}}$ Isolated yields

${ }^{\mathrm{c}}$ Yields were determined by GC-MS analysis 
${ }^{\mathrm{d}}$ All compounds synthetized were fully characterized and found to be in agreement with the literature data ${ }^{85}$. GC retention time and mass spectrometry (EI) data are described.

Finally, regarding the encouraging results obtained in arylation of amines, the efficiency of Eco-Cu ${ }_{8}{ }^{\circledR}$ catalyst was studied in the synthesis of alkyl aryl ethers (Table 8). The synthesis of the latter was already described by Ullmann in his original articles ${ }^{46,47}$. However, despite the recent progress in the catalytic Ullmann reaction, less articles have appeared for the $\mathrm{C}-\mathrm{O}$ than for the $\mathrm{C}-\mathrm{N}$ coupling reaction. The most convenient approach is based on the reaction of aryl bromides or iodides with phenols and usually involves the presence of high ligand and copper loadings $(10-30 \% \mathrm{~mol})^{86-89}$ and elevated temperatures $\left(50-110^{\circ} \mathrm{C}\right)^{87-89}$. In the case of the use of aryl chlorides even higher temperatures are necessary $\left(135^{\circ} \mathrm{C}\right)^{90}$. Importantly, examples involving "ligand-free" coupling of aryl halides with phenols are scarcely described in the literature and they usually require extreme reaction conditions (temperatures of $\left.150-160^{\circ} \mathrm{C}\right)^{91,92}$.

The Eco- $\mathrm{Cu}^{\circledR}$-catalyzed $\mathrm{C}-\mathrm{O}$ bond-forming reactions were very efficient, without ligands and with $\mathrm{Cs}_{2} \mathrm{O}_{3}$ as base. In the presence of $1 \mathrm{~mol} \%$ of $\mathrm{Cu}$, satisfactory to high yields were obtained for various aryl alkyl ethers. Contrary to conventional procedures, the reaction was sensitive to both electronwithdrawing and -donating groups on the substrates, and also to the nature of the halide partner. Indeed good conversion rates were obtained with aryl iodides and aryl bromides in mild conditions (entries 15), whereas strong activating substituents and an increase in the reaction temperature were required to perform the coupling reaction with aryl chlorides (entries 11-12). These conditions were compatible with a wide range of functionalities including nitriles, ketones, ethers, alkyl and nitro groups.

Table 8.Eco- $\mathrm{Cu}^{\circledR}$-catalyzed synthesis of alkyl aryl ethers

Entry $^{\mathrm{a}}$


5<smiles>Ic1ccccc1</smiles><smiles>COc1ccc(O)cc1</smiles>

6<smiles>Brc1ccccc1</smiles><smiles>Cc1cc(C)cc(O)c1</smiles>

$\mathrm{OH}$

7<smiles>Brc1ccccc1</smiles><smiles>COc1ccc(C)cc1</smiles>

8<smiles>Brc1ccccc1</smiles><smiles>O=[N+]([O-])Oc1cccc(O)c1</smiles>

9<smiles>Brc1ccccc1</smiles><smiles>Oc1ccccc1</smiles><smiles>N#Cc1ccc(O)cc1</smiles>

11

10<smiles>O=[N+]([O-])c1ccc(Br)cc1</smiles><smiles>Cc1cc(C)cc(O)c1</smiles>

12<smiles>O=[N+]([O-])c1ccc(Cl)cc1</smiles>

130

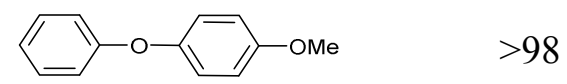

130<smiles>Cc1cc(C)cc(Oc2ccccc2)c1</smiles>

84

130<smiles>COc1ccc(Oc2ccccc2)cc1</smiles>

82

130

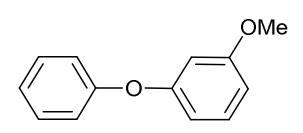

92

$\mathrm{rt}=14.62 \mathrm{~min}$, $\mathrm{m} / \mathrm{z}=200$ (51, $77,92,129$, $157)^{95}$

130

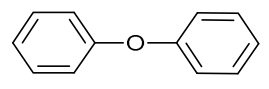

$51^{\mathrm{c}}$

110<smiles>N#Cc1ccc(Oc2ccc([N+](=O)[O-])cc2)cc1</smiles>

$\mathrm{rt}=18.18 \mathrm{~min}$, $\mathrm{m} / \mathrm{z}=240(80$, $108,210)^{96}$

110<smiles>Cc1cc(C)cc(Oc2ccc([N+](=O)[O-])cc2)c1</smiles>
$\mathrm{rt}=17.29 \mathrm{~min}$, $\mathrm{m} / \mathrm{z}=243$ (77, 108, 170, $213)^{97}$

110

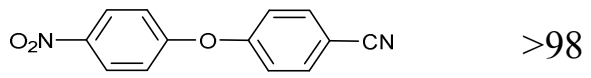

${ }^{\mathrm{a}}$ Reaction conditions: Aryl halide (5 mmol), phenol (6mmol), Eco- $\mathrm{Cu}_{8}{ }^{\circledR}(50 \mu \mathrm{mol}), \mathrm{Cs}_{2} \mathrm{CO}_{3}(10 \mathrm{mmol}), \mathrm{DMF}(5 \mathrm{~mL}), 15 \mathrm{~h}$, argon atmosphere

${ }^{\mathrm{b}}$ Isolated yield

${ }^{c}$ Yields were determined by GC-MS analysis

${ }^{\mathrm{d}}$ All compounds synthetized were fully characterized and found to be in agreement with the literature data: GC retention time / Mass spectrometry (EI) / literature references for NMR spectroscopy are given

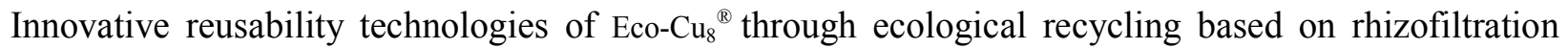
were under investigation"

\section{Experimental Section}

\subsection{General remarks}


NMR spectra were recorded on a Brüker Avance 300 spectrometer at room temperature, ${ }^{1} \mathrm{H}$ frequency is at $300 \mathrm{MHz},{ }^{13} \mathrm{C}$ frequency is at $75 \mathrm{MHz}$. IR spectra were recorded on a Perkin Elmer Spectrum 100 FT-IR spectrometer in ATR mode. GC-MS analyses were performed on a Shimadzu QP2010SE apparatus. Two different methods were used for analysis. Method A: GC-MS (Phenomenex ZB-5MSi Guardian column, $0.25 \mu \mathrm{m} \times 0.25 \mathrm{~mm} \times 30 \mathrm{~m}$ ) with hydrogen as carrier gas using the following temperature program: isothermal at $80^{\circ} \mathrm{C}(4 \mathrm{~min})$, then linear gradient from $80^{\circ} \mathrm{C}$ to $270^{\circ} \mathrm{C}$ at $20^{\circ} \mathrm{C} / \mathrm{min}$.Method B: GC-MS (Phenomenex ZB-5MSi Guardian column, $0.18 \mu \mathrm{m}$ x $0.18 \mathrm{~mm}$ x $20 \mathrm{~m}$ ) with hydrogen as carrier gas using the following temperature program: isothermal at $100^{\circ} \mathrm{C}(1 \mathrm{~min})$, then linear gradient from $100^{\circ} \mathrm{C}$ to $145^{\circ} \mathrm{C}$ at $50^{\circ} \mathrm{C} / \mathrm{min}$, then isothermal at $145^{\circ} \mathrm{C}(0.50 \mathrm{~min})$, then increasing from $145^{\circ} \mathrm{C}$ to $190^{\circ} \mathrm{C}$ at $50^{\circ} \mathrm{C} / \mathrm{min}$, then isothermal at $190^{\circ} \mathrm{C}(0.60 \mathrm{~min})$, and finally increasing from $190^{\circ} \mathrm{C}$ to $320^{\circ} \mathrm{C}$ at $90^{\circ} \mathrm{C} / \mathrm{min}$.GC-MS samples were prepared in dichloromethane using 1,1'-biphenyl as internal standard. Mass spectra were recorded in electron impact (EI) mode at $70 \mathrm{~V}$ and identified by comparison with data of the NIST 11 software library and by comparison of the retention time of the standard compounds. X-ray photoelectron spectroscopy (XPS) analysis were performed with a Kratos Analytical Axis Ultra DLD, using an Al Ka source monochromatized at $1486.6 \mathrm{eV}$. We used a hemispheric analyzer working at pass energy of $50 \mathrm{eV}$ for the global spectrum and $20 \mathrm{eV}$ when focusing on the sole core levels. Direct-injection mass spectrometry was performed with a Micromass Quattro micro APITM, which was combined with HPLC detector and triple quadrupolemass analyser for determining mass-to-charge ratio $(\mathrm{m} / \mathrm{z})$. The transmission electron microscopy (TEM) images were taken using a Jeol 1400 Plus Transmission Electron Microscope at accelerating voltage of $120 \mathrm{kV}$. Ecocatalyst was put in suspension in EtOH 70\% and was dropped off on a grid CF 300-Cu (carbon film on 300 Mesh copper grids).

\subsection{Elemental analyses}

Chemical element analyses of plants and ecocatalysts were determined by ICP-MS analyses (inductively coupled plasma mass spectrometry). ICP-MS analyses were performed using the metal analysis of total dissolved solutes in water. The samples were first digested either in a mixture of hydrochloric acid (37\%) $(8 \mathrm{~mL})$ and nitric acid $(65 \%)(2 \mathrm{~mL})$ (L. multiflorum, E. crassipes and ecocatalysts Eco-Cu ${ }^{\circledR}$ ), or in pure nitric acid (B. monnieri, A. chinensis) using a microwave-assisted digestion. Microwave digestions were performed on a Mileston ETHOS Touch Control device with two different temperature programs: 1 . Linear gradient from 20 to $90^{\circ} \mathrm{C}$ at $10^{\circ} \mathrm{C} / \mathrm{mn}$, then from 90 to $170^{\circ} \mathrm{C}$ at $16^{\circ} \mathrm{C} / \mathrm{mn}$, then from 170 to $210^{\circ} \mathrm{C}$ at $10^{\circ} \mathrm{C} / \mathrm{mn}$ and then $20 \mathrm{~min}$ isothermal at $210^{\circ} \mathrm{C}(\mathrm{L}$. multiflorum, E. crassipes, and ecocatalysts Eco-Cu $\left.{ }^{\circledR}\right)$; 2. Linear gradient from $20{ }^{\circ} \mathrm{C}$ to $180^{\circ} \mathrm{C}$ at 32 ${ }^{\circ} \mathrm{C} / \mathrm{mn}$, then $10 \mathrm{~min}$ isothermal at $180^{\circ} \mathrm{C}$ (B. monnieri, A. chinensis). Samples were then diluted to 0.1 mg. $\mathrm{L}^{-1}$ in $2.5 \%$ aqueous nitric acid. Three blanks were recorded for each step of the digestion and dilution procedure. ICP-MS analyses were performed on a Thermo Scientific ${ }^{\mathrm{TM}}$ ELEMENT XR ${ }^{\mathrm{TM}}$ ICP-MS.All analysis results were performed in triplicate.

\subsection{Phytoextraction}




\section{Study site}

The study site is the "Mine de l'Etoile", in the vicinity of Lubumbashi, a "locus classicus" of Cu and Co hyperaccumulation by plants in Katanga (Democratic Republic of the Congo) ${ }^{22}$. Soil of "Mine de l'Etoile" is contaminated by tailings which were spontaneously colonized by some Cu-Co tolerant species. Total $\mathrm{Cu}$ concentrations in soil vary from 10,000 to $30,000 \mathrm{mg} \cdot \mathrm{kg}^{-1} 20$.

A. chinensis L. Hook.f. \& Arn. (Asteraceae) is a perennial pseudo-metallophyte presenting a large variation of $\mathrm{Cu}$ concentrations in shoots in natura ${ }^{23,24}$. Plant shoots of 20 individuals of $A$. chinensis were collected all over the "Mine de l'Etoile" (11 $31^{\circ} \mathrm{S} ; 27^{\circ} 35^{\prime} \mathrm{E}, 1277 \mathrm{~m}$ asl). This site is characterized by a subtropical humid climate including a rainy season (from November to March) and a dry season (from May to September). Maximum density of individuals (ind) of $A$. chinensis were estimated to $15 \mathrm{ind} / \mathrm{m}^{2}$ from field observations (i.e. mean of 10 quadrats of $\mathrm{m}^{2}$ ). Biomass productivity (BP) of monospecific crop of $A$. chinensis was then estimated: $\mathrm{BP}=$ mean biomass of $A$. chinensis individual x 15 .

\section{Determinations of Cu concentration in plant shoots}

After harvesting, plants were carefully brushed (whole shoots), washed with Alconox ${ }^{\circledR} 1 \%$ in deionized water, dried at $65^{\circ} \mathrm{C}$ for $48 \mathrm{~h}^{22}$ and weighted. Determination of $\mathrm{Cu}$ concentration in $A$. chinensis was performed in two steps. A mass of leaves was digested using a mixture of $8 \mathrm{~mL} \mathrm{HNO}_{3}$ and $2 \mathrm{~mL} \mathrm{HCl}^{98}$ Vessels containing the mix were heated by microwaves for digestion ${ }^{24,}{ }^{99}$.Then, $\mathrm{Cu}$ concentration in samples was determined by ICP-MS.

\section{Evaluation of phytoextraction parameters}

$\mathrm{Cu}$ amount phytoextracted per hectare and per year was calculated by the following formula:

$\mathrm{YCu}=\mathrm{FCu}$. Ybio

FCu: Average fraction of $\mathrm{Cu}$ in $A$. chinensis biomass

Ybio: Biomass productivity of hyperaccumulator $(\mathrm{kg} / \mathrm{ha} / \mathrm{year})$

$\mathrm{YCu}$ : Total $\mathrm{Cu}$ gain $(\mathrm{g} / \mathrm{ha} /$ year)

\subsection{Rhizofiltration}

\section{Germination and growth}

B. monnieri was bought directly in a garden center Jardiland. It was then immersed in a hydroponic reservoir with a natural substrate called Manado (pozzolan) and $17 \mathrm{~L}$ of distillated water. The plants were fed once every week with a fertilizer called "S7 Vitamix", mainly containing $0.65 \% \mathrm{~K}_{2} \mathrm{O}, 0.14 \%$ $\mathrm{Mg}, 0.41 \% \mathrm{~S}, 0.06 \% \mathrm{~N}, 0.065 \% \mathrm{Fe}, 0.026 \% \mathrm{Mn}$. The plants were grown under neon light (12 h per day) and under ambient temperature. The cultivation lasted 5 months in these conditions before the beginning of copper accumulation. 
L. multiflorum was grown in our lab. Seeds were first transferred in Fleximix Root Riot Organic Starter Cubes ${ }^{\odot}, 82 \%$ of seeds were germinated after 9 days. The culture plate was placed in a shallow hydroponic reservoir, to be sure that only the roots of the plants were immersed in water at ambient temperature. The plants were fed with a fertilizer called "water lily dream" containing $1 \% \mathrm{~K}_{2} \mathrm{O}, 0.14 \%$ Mo, $0.0028 \% \mathrm{Zn}, 0.0027 \% \mathrm{Cu}, 0.0004 \% \mathrm{Li}$. They were exposed during 8 weeks, $12 \mathrm{~h}$ per day, under mercury lamp UV (37,000 lumens), before the beginning of copper accumulation.

E. crassipes was bought in a garden center Jardiland. They were put in an outdoor pool with water during 6 months without additional fertilizer.

\section{Conditions of accumulation}

After five months of growth, B. monnieri was placed in another hydroponic reservoir, without substrate, and with $17 \mathrm{~L}$ of an aqueous solution made of distillated water and $40 \mathrm{mg} / \mathrm{L}$ of $\mathrm{Cu}\left(\mathrm{NO}_{3}\right)_{2} .3 \mathrm{H}_{2} \mathrm{O}(10.5 \mathrm{mg} / \mathrm{L}$ of $\mathrm{Cu})$. The accumulation occurred under ambient temperature, and under neon light (12 h per day), during 7 days.

After 8 weeks of growth, L. multiflorum was exposed to an aqueous media made of distillated water with $40 \mathrm{mg} / \mathrm{L}$ of $\mathrm{Cu}\left(\mathrm{NO}_{3}\right)_{2} .3 \mathrm{H}_{2} \mathrm{O}(10.5 \mathrm{mg} / \mathrm{L}$ of $\mathrm{Cu})$. The accumulation occurred under ambient temperature, and under mercury lamp UV (37,000 lumens), during 7 days.

After 6 months in the pool, E. crassipes was exposed to an aqueous solution made of $40 \mathrm{mg} / \mathrm{L}$ of $\mathrm{Cu}\left(\mathrm{NO}_{3}\right)_{2} .3 \mathrm{H}_{2} \mathrm{O}(10.5 \mathrm{mg} / \mathrm{L}$ of $\mathrm{Cu})$. The accumulation occurred outside (the plants suffered from necrosis quickly in inside pool), during 7 days.

\section{Crops}

The plants were collected and separated into roots and aerial parts. Plant tissues were washed with distillated water to remove any metallic particles attached to the plant surfaces. Then the biomass was dried in an oven at $80^{\circ} \mathrm{C}$ during $48 \mathrm{~h}$.

\section{Evaluation of rhizofiltration parameters}

Biomass measuring:

Once harvested and dried, the root biomass and the shoot biomass were weighted for each plant.

$\mathrm{BCF}$ (bioconcentration factor):

The BCF was calculated as the ratio of a given element concentration in the plant tissues $(\mathrm{P}, \mathrm{mg} / \mathrm{kg}$ dry weight) at harvest to the concentration of the element in the effluent (E, mg/L) according to Eq.(1)

\section{$\mathbf{B C F}=\mathbf{P} / \mathbf{E}$}

TF (translocation factor):

TF was calculated by dividing the $\mathrm{Cu}$ concentration in shoot tissues $\left(\mathrm{A}_{\mathrm{s}}, \mathrm{mg} / \mathrm{kg}\right.$ dry weight) by the concentration of $\mathrm{Cu}$ accumulated in root tissues ( $\mathrm{A}_{\mathrm{r}} \mathrm{mg} / \mathrm{kg}$ dry weight) (Eq.(2)):

$\mathbf{T F}=\left(\mathbf{A}_{\mathbf{s}} / \mathbf{A}_{\mathbf{r}}\right)$ 
Metal concentrations in roots and shoots were determined by ICP-MS. The procedure is the same as described in section 3.2., Elemental analyses.

\subsection{Preparation of Eco-Cu ${ }^{\circledR}$ catalysts}

Eco- $\mathrm{Cu}^{\circledR}$ catalysts were prepared either from roots of plants used for rhizofiltration, or from harvested leaves of plants used for phytoextraction. Biomasses were first dried into an oven at $80^{\circ} \mathrm{C}$, then thermally treated in an oven using the following temperature program: linear gradient from 20 to $550^{\circ} \mathrm{C}(1 \mathrm{~h})$ and then 4 hours at $550^{\circ} \mathrm{C}$ before a slow cooling overnight to obtain ashes $\left(\mathrm{Eco}^{-\mathrm{Cu}_{1}{ }^{\circledR}}(A\right.$. chinensis $),$ Eco- $\mathrm{Cu}_{3}{ }^{\circledR}($ B. monnieri $)$, Eco-Cu ${ }_{5}{ }^{\circledR}($ L. multiflorum $)$ and Eco-Cu ${ }_{7}{ }^{\circledR}($ E. crassipes $\left.)\right)$. Thereafter the ashes obtained were subjected to a chemical treatment. The typical procedure used was as follow: around $50 \mathrm{mg}$ of ashes were suspended in concentrated hydrochloric acid $(5 \mathrm{~mL})$. The solutions were stirred at $80{ }^{\circ} \mathrm{C}$ for $4 \mathrm{~h}$ and then evaporated to dryness under vacuum to get Eco-Cu ${ }_{2}^{\circledR}$ (A. chinensis), Eco- $\mathrm{Cu}_{4}{ }^{\circledR}$ (B. monnieri), Eco-Cu ${ }_{6}{ }^{\circledR}$ (L. multiflorum) and Eco-Cu ${ }_{8}{ }^{\circledR}$ (E. crassipes)) respectively, as yellow powders. Eco- $\mathrm{Cu}^{\circledR}$ catalysts were stored under vacuum in a desiccator.

Thermic treatment: Eco- $\mathrm{Cu}_{1}{ }^{\circledR}, \mathrm{Eco}-\mathrm{Cu}_{3}{ }^{\circledR}, \mathrm{Eco} \mathrm{Cu}_{5}{ }^{\circledR}, \mathrm{Eco}^{-\mathrm{Cu}}{ }_{7}{ }^{\circledR}$

Thermic and chemical treatment; Eco- $\mathrm{Cu}_{2}{ }^{\circledR}, \mathrm{Eco}-\mathrm{Cu}_{4}{ }^{\circledR}, \mathrm{Eco}-\mathrm{Cu}_{6}{ }^{\circledR}, \mathrm{Eco}-\mathrm{Cu}_{8}{ }^{\circledR}$

\subsection{Characterization of Eco-Cu ${ }^{\circledR}$ catalysts}

\subsubsection{Chemical element analysis}

ICP-MS was used to determine the composition of the various ecocatalysts prepared. ICP-MS analyses were performed as described section 3.2. Elemental analyses.

\subsubsection{Acidity characterization}

Pyridine-FTIR (Fourier transform infrared spectroscopy):

Excess pyridine was adsorbed on catalysts, then the samples were degassed for $15 \mathrm{~min}$ at $23{ }^{\circ} \mathrm{C}\left(10^{-3}\right.$ $\mathrm{Pa})$ and a first IR spectrum was recorded. The samples were then degassed for $30 \mathrm{~min}$ at $150{ }^{\circ} \mathrm{C}\left(10^{-3}\right.$ $\mathrm{Pa}$ ) to eliminate the physisorbed pyridine and a second IR spectrum was recorded.

Rearrangement of $\alpha$-bromopropiophenone cyclic acetal:

A solution of $\alpha$-bromopropiophenone cyclic acetal $(75.8 \mathrm{mg}, 295 \mu \mathrm{mol}, 1$ equiv.) in 1,2dichlorobenzene $(3.35 \mathrm{~mL}$ ) was poured onto catalyst (mass corresponding to $12.4 \mu \mathrm{mol}$ of $\mathrm{Cu}, 0.04$ equiv.). Thereafter water was added $(5.31 \mu \mathrm{L}, 295 \mu \mathrm{mol}, 1$ equiv.) and the resulting suspension was stirred at $175^{\circ} \mathrm{C}$ for $20 \mathrm{~h}$. The crude was analyzed by GC-MS (method B).

\subsubsection{Analytic test of Eco-Cu ${ }_{8}{ }^{\circledR}$}


$\mathrm{EcoCu}_{8}{ }^{\circledR}(8.1 \mu \mathrm{mol}$ of $\mathrm{Cu}, 5 \mathrm{mg})$ was suspended into aq. $30 \mathrm{w} \%$ ammonia $(200 \mu \mathrm{L})$. The suspension was vortexed and the liquid phase turned deep blue within 1 minute demonstrating the presence of $\mathrm{Cu}^{2+}$ into our catalyst by forming $\left[\mathrm{Cu}\left(\mathrm{NH}_{3}\right)_{4}\right]^{2+}$ complexes. The mixture was centrifuged for better observation of the solution.

\subsection{General procedure for catalytic Ullmann coupling reaction and analysis of reaction products}

The general procedure is described here with the case of 1 H-pyrazole.

To a solution of $1 \mathrm{H}$-pyrazole $(510 \mathrm{mg}, 7.5 \mathrm{mmol})$ and iodobenzene $(560 \mu \mathrm{L}, 5.0 \mathrm{mmol})$ in dry DMF (5 $\mathrm{mL})$ were sequentially added: Eco-Cu ${ }^{\circledR}$ catalysts $(3.3 \mathrm{mg}, 0.05 \mathrm{mmol}$ of $\mathrm{Cu})$ and $\mathrm{Cs}_{2} \mathrm{CO}_{3}(3.25 \mathrm{~g}, 10.0$ $\mathrm{mmol}$ ). The resulting mixture was stirred at $90^{\circ} \mathrm{C}$ under inert atmosphere for $15 \mathrm{~h}$. After cooling to room temperature, the crude was diluted with ethyl acetate, filtered and concentrated under reduced pressure. The resulting residue was purified on a silica gel column (Cyclohexane/ethyl acetate 8:2) to give 1-phenyl-1H-pyrazole as a colourless oil (647 mg, 90\% yield). ${ }^{1} \mathrm{H}$ NMR (300 MHz, $\left.\mathrm{CDCl}_{3}\right)$ ppm: $\delta=7.93-7.92(\mathrm{dd}, 1 \mathrm{H}), 7.76-7.70(\mathrm{~m}, 3 \mathrm{H}), 7.49-7.42(\mathrm{~m}, 2 \mathrm{H}), 7.32-7.26(\mathrm{~m}, 1 \mathrm{H}), 6.48-6.46(\mathrm{~m}, 1 \mathrm{H})$;

${ }^{13} \mathrm{C} \mathrm{NMR}\left(75 \mathrm{MHz}, \mathrm{CDCl}_{3}\right)$ ppm: $\delta=143.6,142.7,131.9,129.2,128.9,121.7,110.1 ; \mathrm{MS}(\mathrm{EI}): \mathrm{m} / \mathrm{z}$ $144\left(\mathrm{M}^{+}, 100 \%\right), 117,104,90,77,51$.

\section{Conclusion}

The aim of this work was to prepare and to study novel copper catalysts based on using $\mathrm{Cu}$ hyperaccumulator plants which present an interest for the phytoremediation of mining sites and contaminated aqueous systems. From these studies, it may be concluded that the new catalytic systems show a very interesting activity in the arylation of nucleophiles. The chemistry described in this article demonstrated that $\mathrm{Eco}-\mathrm{Cu}^{\circledR}$ catalysts are original and show valuable physicochemical properties, especially regarding their polymetallic composition. Eco-Cu${ }^{\circledR}$ catalysts offer unexplored potential for coupling reactions, especially those deriving from rhizofiltration (E. crassipes). Eco-Cu ${ }^{\circledR}$-catalyzed C$\mathrm{N}$ and $\mathrm{C}-\mathrm{O}$ bond forming reactions are interesting methods for the synthesis of tertiary amines and aryl ethers. The development of these new ecocatalytic systems represents exciting opportunities to valorize phytoremediation of polluted ecosystems and for future organic synthesis. The combination of these beneficial properties will undoubtedly prompt further research efforts toward the development of ecocatalysis.

\section{Acknowledgments}

The authors would like to thank the Centre National de la Recherche Scientifique (CNRS) for financial support. Belgian Fund for Scientific Research (FRSFNRS) are acknowledged too, for financial support to Bastien Lange, who is a research fellow of the Fonds pour la Recherche dans l'Industrie et l'Agriculture (FRIA, Belgium). Finally, we thank the CRESICA and the University of New Caledonia (M. Meyer and A. Douyere) for the TEM images.

\section{References and Notes}


1. R. D. Reeves and A. J. M. Baker, Phytoremediation of Toxic Metals, Using Plants to Clean Up the Environment, Wiley and Sons, Inc.2000, 2000.

2. Y.-M. Li, R. Chaney, E. Brewer, R. Roseberg, J. S. Angle, A. Baker, R. Reeves and J. Nelkin, Plant and Soil, 2003, 249, 107-115.

3. C. Grison, M. Mazel, A. Sellini, V. Escande, J. Biton and C. Grison, Environ. Sci. Pollut. Res., 2014, 1-10.

4. G. Losfeld, R. Mathieu, L. L'Huillier, B. Fogliani, T. Jaffré and C. Grison, Environ. Sci. Pollut. Res., 2015, 22, 5608-5619.

5. G. Losfeld, V. Escande, T. Mathieu and C. Grison, Tech. Ing., 2011, IN 135, 1-8.

6. C. Grison, Environ. Sci. Pollut. Res. Int., 2015, 22, 5589-5591.

7. C. Grison, V. Escande, E. Petit, L. Garoux, C. Boulanger and C. Grison, RSC Adv., 2013, 3, 22340.

8. V. Escande, L. Garoux, C. Grison, Y. Thillier, F. Debart, J.-J. Vasseur, C. Boulanger and C. Grison, Appl. Catal., B, 2014, 146, 279-288.

9. G. Losfeld, P. V. de La Blache, V. Escande and C. Grison, Green Chem. Lett. Rev., 2012, 5, 451-456.

10. G. Losfeld, P. Vidal de la Blache, V. Escande and C. Grison, WIT Trans. Ecol. Environ., 2012, 1, 563-575.

11. G. Losfeld, V. Escande, T. Jaffré, L. L'Huillier and C. Grison, Chemosphere, 2012, 89, $907-$ 910.

12. G. Losfeld, V. Escande, P. Vidal de La Blache, L. L’Huillier and C. Grison, Catal. Today, 2012, 189, 111-116.

13. Y. Thillier, G. Losfeld, V. Escande, C. Dupouy, J.-J. Vasseur, F. Debart and C. Grison, RSC Adv., 2013, 3, 5204.

14. V. Escande, T. K. Olszewski, E. Petit and C. Grison ChemSusChem, 2014, 7, 1915-1923.

15. V. Escande, T. K. Olszewski and C. Grison, C.R. Chim., 2014, 17, 731-737.

16. V. Escande, B. L. Renard and C. Grison, Environ. Sci. Pollut. Res. Int., 2015, 22, 5633-5652.

17. V. Escande, A. Velati, C. Garel, B.-L. Renard, E. Petit and C. Grison, Green Chem., 2015, 17, 2188-2199.

18. C. Garel, B.-L. Renard, V. Escande, A. Galtayries, P. Hesemann and C. Grison, Appl. Catal., A, 2015, 504, 272-286.

19. C. L. Banza, T. S. Nawrot, V. Haufroid, S. Decree, T. De Putter, E. Smolders, B. I. Kabyla, O. N. Luboya, A. N. Ilunga, A. M. Mutombo and B. Nemery, Environ. Res., 2009, 109, 745-752.

20. O. Pourret, B. Lange, D. Houben, G. Colinet, M. Shutcha and M.-P. Faucon, J. Geochem. Explor., 2015, 149, 87-96.

21. M. N. Shutcha, M. M. Mubemba, M.-P. Faucon, M. N. Luhembwe, M. Visser, G. Colinet and P. Meerts, Int. J. Phytorem., 2010, 12, 616-632.

22. M. P. Faucon, M. N. Shutcha and P. Meerts, Plant and Soil, 2007, 301, 29-36.

23. M.-P. Faucon, Pl. Ecol. Evol., 2010, 143, 5-18.

24. B. Lange, M.-P. Faucon, P. Meerts, M. Shutcha, G. Mahy and O. Pourret, Plant and Soil, 2014, 379, 275-287.

25. H. Peng, Q. Wang-Müller, T. Witt, F. Malaisse and H. Küpper, Environ. Exp. Bot., 2012, 79, 58-65.

26. M.-P. Faucon, F. Chipeng, N. Verbruggen, G. Mahy, G. Colinet, M. Shutcha, O. Pourret and P. Meerts, Environ. Exp. Bot., 2012, 84, 11-16.

27. B. Lange, O. Pourret, P. Meerts, P. Jitaru, B. Cancès, C. Grison and M.-P. Faucon, Chemosphere, 2016, 146, 75-84.

28. A. Kabata-Pendias, CRC press, 2010, p. 413.

29. L. Y. Jiang, X. E. Yang and Z. L. He, Chemosphere, 2004, 55, 1179-1187.

30. X.-E. Yang, H.-Y. Peng, L.-Y. Jiang and Z.-L. He, Int. J. Phytorem., 2005, 7, 69-83. 
31. A. Kolbas, M. Mench, R. Herzig, E. Nehnevajova and C. M. Bes, Int. J. Phytorem., 2011, 13, $55-76$.

32. R. S. Morrison, R. R. Brooks, R. D. Reeves and F. Malaisse, Plant and Soil, 1979, 53, 535-539.

33. S. Sinha and P. Chandra, Water Air Soil Pollut., 1990, 51, 271-276.

34. B. A. Lesniewska, J. Messerschmidt, N. Jakubowski and A. Hulanicki, Sci. Total Environ., 2004, 322, 95-108.

35. T. E. Romanova, O. V. Shuvaeva and L. A. Belchenko, Int. J. Environ. Anal. Chem., 2015, 1-9.

36. X. Yu, S. Chai, X. Kuang, C. Su, F. Pan, L. Fang, Q. Su and P. K. Davies, J. Am. Ceram. Soc., 2013, 96, 2510-2514.

37. J. C. Rivière and S. Myhra, Handbook of surface and interface analysis: methods for problemsolving, CRC Press, 2009.

38. L. Gianelli, V. Amendola, L. Fabbrizzi, P. Pallavicini and G. G. Mellerio, Rapid Commun. Mass Spectrom., 2001, 15, 2347-2353.

39. R. G. Pearson, J. Chem. Educ., 1968, 45, 581.

40. R. G. Pearson, Inorg. Chim. Acta, 1995, 240, 93-98.

41. E. P. Parry, J. Catal., 1963, 2, 371-379.

42. M. I. Zaki, M. A. Hasan, F. A. Al-Sagheer and L. Pasupulety, Colloids Surf., A, 2001, 190, 261-274.

43. M. V. Baldovi, A. Corma, V. Fornes, H. Garcia, A. Martinez and J. Primo, J. Chem. Soc., Chem. Commun., 1992, 949-951.

44. A. Corma, H. Garcia, A. Primo and A. Domenech, New J. Chem., 2004, 28, 361-365.

45. T.-L. Ho, Chem. Rev., 1975, 75, 1-20.

46. F. Ullmann, Ber. Dtsch. Chem. Ges., 1903, 36, 2382-2384.

47. F. Ullmann, Ber. Dtsch. Chem. Ges., 1904, 37, 853-854.

48. S. V. Ley and A. W. Thomas, Angew. Chem. Int. Ed., 2003, 42, 5400-5449.

49. I. P. Beletskaya and A. V. Cheprakov, Coord. Chem. Rev., 2004, 248, 2337-2364.

50. A. J. Hickman and M. S. Sanford, Nature, 2012, 484, 177-185.

51. G. Evano and N. Blanchard Copper-Mediated Cross-Coupling Reactions, Wiley-VCH, 2013.

52. G. Evano, N. Blanchard and M. Toumi, Chem. Rev., 2008, 108, 3054-3131.

53. T. Manifar, S. Rohani, T. P. Bender, H. B. Goodbrand, R. Gaynor and M. Saban, Ind. Eng. Chem. Res., 2005, 44, 789-798.

54. H. Kaddouri, V. Vicente, A. Ouali, F. Ouazzani and M. Taillefer, Angew. Chem. Int. Ed., 2009, 48, 333-336.

55. D. Ma, Y. Zhang, J. Yao, S. Wu and F. Tao, J. Am. Chem. Soc., 1998, 120, 12459-12467.

56. A. Shafir and S. L. Buchwald, J. Am. Chem. Soc., 2006, 128, 8742-8743.

57. J. C. Antilla, A. Klapars and S. L. Buchwald, J. Am. Chem. Soc., 2002, 124, 11684-11688.

58. A. Klapars, X. Huang and S. L. Buchwald, J. Am. Chem. Soc., 2002, 124, 7421-7428.

59. I. Goldberg, Ber. Dtsch. Chem. Ges., 1906, 39, 1691-1692.

60. I. Goldberg, Ber. Dtsch. Chem. Ges., 1907, 40, 4541-4546.

61. H. Weingarten, J. Org. Chem., 1964, 29, 3624-3626.

62. A. J. Paine, J. Am. Chem. Soc., 1987, 109, 1496-1502.

63. H. L. Aalten, G. van Koten, D. M. Grove, T. Kuilman, O. G. Piekstra, L. A. Hulshof and R. A. Sheldon, Tetrahedron, 1989, 45, 5565-5578.

64. M. Mansour, R. Giacovazzi, A. Ouali, M. Taillefer and A. Jutand, Chem. Commun., 2008, DOI: 10.1039/b814364a, 6051-6053.

65. M. Taillefer, N. Xia and A. Ouali, Angew. Chem. Int. Ed., 2007, 46, 934-936.

66. Z.-L. Xu, H.-X. Li, Z.-G. Ren, W.-Y. Du, W.-C. Xu and J.-P. Lang, Tetrahedron, 2011, 67, 5282-5288.

67. P.-S. Wang, C.-K. Liang and M.-k. Leung, Tetrahedron, 2005, 61, 2931-2939.

68. A. Kiyomori, J.-F. Marcoux and S. L. Buchwald, Tetrahedron Lett., 1999, 40, 2657-2660. 
69. E. Shirakawa, T. Yamagami, T. Kimura, S. Yamaguchi and T. Hayashi, J. Am. Chem. Soc., 2005, 127, 17164-17165.

70. I. P. Beletskaya, D. V. Davydov and M. Moreno-Mañas, Tetrahedron Lett., 1998, 39, 56215622.

71. J.-F. Marcoux, S. Doye and S. L. Buchwald, J. Am. Chem. Soc., 1997, 119, 10539-10540.

72. L. Zhu, G. Li, L. Luo, P. Guo, J. Lan and J. You, J. Org. Chem., 2009, 74, 2200-2202.

73. Q. Yang, Y. Wang, D. Lin and M. Zhang, Tetrahedron Lett., 2013, 54, 1994-1997.

74. Q. Yang, Y. Wang, B. Zhang and M. Zhang, Chin. J. Chem., 2012, 30, 2389-2393.

75. R. Zhu, L. Xing, X. Wang, C. Cheng, D. Su and Y. Hu, Adv. Synth. Catal., 2008, 350, 12531257.

76. Q. Yang, Y. Wang, L. Yang and M. Zhang, Tetrahedron, 2013, 69, 6230-6233.

77. A. Y. Kim, H. J. Lee, J. C. Park, H. Kang, H. Yang, H. Song and K. H. Park, Molecules, 2009, 14, 5169.

78. S. Uk Son, I. Kyu Park, J. Park and T. Hyeon, Chem. Commun., 2004, 778-779.

79. P.-F. Larsson, A. Correa, M. Carril, P.-O. Norrby and C. Bolm, Angew. Chem. Int. Ed., 2009, 48, 5691-5693.

80. B. Zhang, J. Song, H. Liu, J. Shi, J. Ma, H. Fan, W. Wang, P. Zhang and B. Han, Green Chem., 2014, 16, 1198-1201.

81. G. Fan, H. Zhang, S. Cheng, Z. Ren, Z. Hu and Z. Wang, Aust. J. Chem., 2008, 61, 610-614.

82. A. Sud, R. M. Deshpande and R. V. Chaudhari, Catal. Commun., 2007, 8, 183-186.

83. E. Ismalaj, G. Strappaveccia, E. Ballerini, F. Elisei, O. Piermatti, D. Gelman and L. Vaccaro, ACS Sustainable Chem. Eng., 2014, 2, 2461-2464.

84. F. Monnier and M. Taillefer, Angew. Chem. Int. Ed., 2008, 47, 3096-3099.

85. H.-J. Cristau, Pascal P. Cellier, J.-F. Spindler and M. Taillefer, Eur. J. Org. Chem., 2004, 2004, 695-709.

86. Q. Cai, B. Zou and D. Ma, Angew. Chem., 2006, 118, 1298-1301.

87. X. Lv and W. Bao, J. Org. Chem., 2007, 72, 3863-3867.

88. H. Rao, Y. Jin, H. Fu, Y. Jiang and Y. Zhao, Chem. Eur. J., 2006, 12, 3636-3646.

89. B. H. Lipshutz, J. B. Unger and B. R. Taft, Org. Lett., 2007, 9, 1089-1092.

90. N. Xia and M. Taillefer, Chem. Eur. J., 2008, 14, 6037-6039.

91. E. Sperotto, J. G. de Vries, G. P. M. van Klink and G. van Koten, Tetrahedron Lett., 2007, 48, 7366-7370.

92. J. W. W. Chang, S. Chee, S. Mak, P. Buranaprasertsuk, W. Chavasiri and P. W. H. Chan, Tetrahedron Lett., 2008, 49, 2018-2022.

93. H.-J. Cristau, P. P. Cellier, S. Hamada, J.-F. Spindler and M. Taillefer, Org. Lett., 2004, 6, 913916.

94. N. Xia and M. Taillefer, Chemistry, 2008, 14, 6037-6039.

95. N. Jalalian, E. E. Ishikawa, L. F. Silva and B. Olofsson, Org. Lett., 2011, 13, 1552-1555.

96. F. Li, Q. Wang, Z. Ding and F. Tao, Org. Lett., 2003, 5, 2169-2171.

97. A. Ouali, J.-F. Spindler, H.-J. Cristau and M. Taillefer, Adv. Synth. Catal., 2006, 348, 499-505.

98. B. Avula, Y.-H. Wang, T. J. Smillie, N. S. Duzgoren-Aydin and I. A. Khan, J. Agric. Food Chem., 2010, 58, 8887-8894.

99. I. Lavilla, A. V. Filgueiras and C. Bendicho, J. Agric. Food Chem., 1999, 47, 5072-5077. 
Ullmann reaction through ecocatalysis: insights from bioressource and synthetic potential

Guillaume Clavé ${ }^{1}$, Claire Garel ${ }^{1}$, Brice-Loïc Renard ${ }^{1}$, Tomasz K. Olszewski, ${ }^{2}$ Bastien Lange ${ }^{3,4}$, Mylor Shutcha ${ }^{5}$, Michel-Pierre Faucon ${ }^{3}$, Claude Grison*

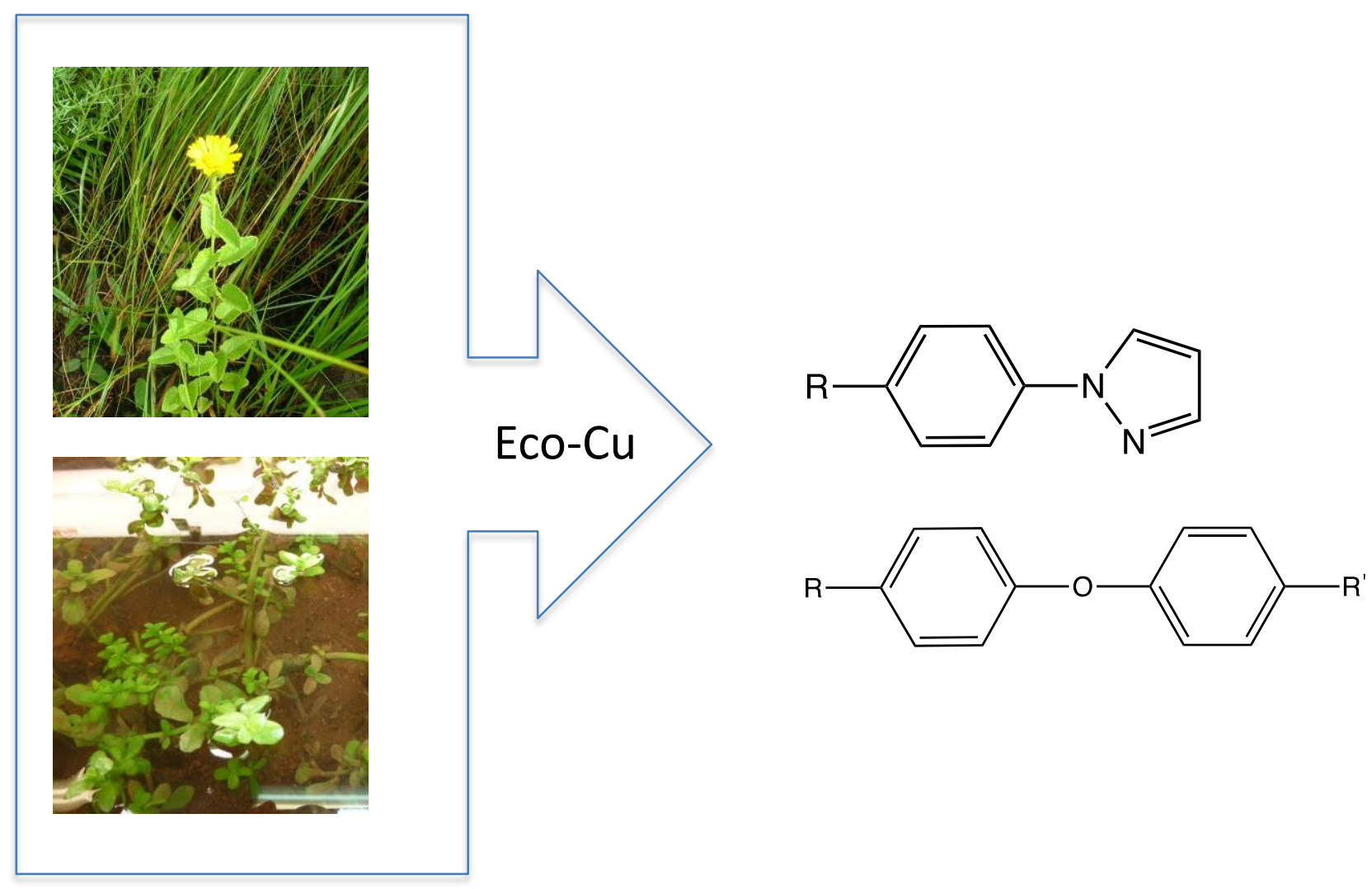

